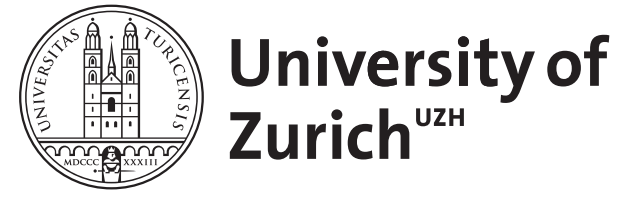
Archive

University of Zurich

University Library

Strickhofstrasse 39

CH-8057 Zurich

www.zora.uzh.ch

Year: 2013

\title{
A tribute to Robin Hochstrasser
}

Hamm, Peter ; Zewail, Ahmed H ; Fleming, Graham R

DOI: https://doi.org/10.1016/j.chemphys.2013.05.003

Posted at the Zurich Open Repository and Archive, University of Zurich

ZORA URL: https://doi.org/10.5167/uzh-84094

Journal Article

Accepted Version

Originally published at:

Hamm, Peter; Zewail, Ahmed H; Fleming, Graham R (2013). A tribute to Robin Hochstrasser. Chemical Physics, 422:1-7.

DOI: https://doi.org/10.1016/j.chemphys.2013.05.003 


\title{
A Tribute to Robin Hochstrasser
}

\author{
${ }^{1}$ Peter Hamm, ${ }^{2}$ Ahmed H. Zewail, ${ }^{3}$ Graham R. Fleming \\ ${ }^{1}$ University of Zurich, Zurich, Switzerland, ${ }^{2}$ California Institute of Technology, Pasadena, \\ USA, ${ }^{3}$ Lawrence Berkeley National Lab, Berkeley, USA.
}

This Special Issue was originally planed to honor Robin Hochstrasser's long-lasting commitment as Editor of Chemical Physics. Events took a sad turn when we heard of Robin's passing. The Special Issue is a collection of research papers from former co-workers of Robin, as well as from close friends and colleagues. As such, this Special Issue documents in a sadly timely fashion the tremendous impact Robin has had on the community and the breadth of his research. In particular the latter is reflected in the wide range of research fields from his former co-workers. Starting their career in Robin's lab, they went on to develop their own research with the inspiration they received from Robin. The large number of people that had the privilege to interact with Robin, many of whom contribute to this Special Issue, guarantees that his spirit and his view of science will live on. As briefly discussed below, the collection of papers in this Special Issue gives the reader an idea to what extent this statement is correct.

Robin influenced and led not just one, but several generations of physical chemists and biophysicists. By striking out into the new field of ultrafast spectroscopy when it was just being born, Robin changed the nature of spectroscopy. Robin realized well before others that moving to the picosecond and shorter timescales was not just about measuring faster and faster events, but was about revealing and understanding the fundamental processes that underlay all condensed phase chemical and biochemical phenomena. Robin went on to apply his techniques, especially those involving infrared ultrashort pulses to biophysical problems, especially 
peptide and protein structure and dynamics, this, at a time when it was far from fashionable for 'real' physical chemists to study biological systems. But Robin did not follow fashion or fads, rather his own insatiable curiosity and intellectual agenda. A glance at Robin's publications [1-505] reveals the astonishing range of topics and the consistency in setting new benchmarks.

Over the last 15 years, Robin's research strongly focused on 2D IR spectroscopy and its applications to study structure and ultrafast dynamics of all sorts of molecular systems, ranging from small molecules to proteins, with unprecedented detail. His groups was the first to introduce that technique in 1998 [117], and it underwent a tremendous development since then. From a methodology side, the development is documented in the paper by Martin Zanni, who spends significant effort to simplify the technique, up to the point that he is currently commercializing it in order to make 2D IR spectroscopy available to a wider community. During these 15 years, quite a number of students and postdocs were trained in Robin's lab and went on to become successful professors all around the world, continuing to develop 2D IR spectroscopy. Some of them contributed to this Special Issue, for example Igor Rubtsov, who uses a variant of 2D spectroscopy, relaxation assisted 2D IR spectroscopy, to measure vibrational energy transport in molecular chains, and Nien-Hui Ge, who applies dual frequency 2D-IR spectroscopy to elucidate correlation between two modes in ethyl diazoacetate.

2D spectroscopy covering the $\mathrm{THz}$ to the UV spectral range was picked up by many other research groups worldwide, not directly connected to Robin, as a promising new technique. An estimated number of 50-70 research groups now pursue 2D optical spectroscopy. Examples are found in the paper of Charles B. Harris, a long-standing friend of Robin, who studies the mass effect on rotational diffusion of small solutes in solution, and in the paper of Minhaeng Cho, which reports on the ultrafast intermolecular vibrational excitation transfer from a solute into the solvent. Majed Chergui, a fellow editor of Chemical Physics, now pushes 2D 
spectroscopy into the UV range, and lays the foundations of $2 \mathrm{D}$ UV spectroscopy of tryptophan in his paper. From a theoretical point of view, 2D spectroscopy opened many new avenues. For example, Wolfgang Domcke, another fellow editor of Chemical Physics, discusses the calculation of third-order optical signals via a driven Schrödinger equation with applications for $2 \mathrm{D}$ spectroscopy, and Shaul Mukamel simulates the 2D IR and stimulated resonance Raman spectra of the photoactive yellow protein.

Quite recently, Robin applied 2D IR spectroscopy to study the structure of the influenza A channel [10], to that of amyloid fibrils [25], as well as the dynamics of water confined in a protein environment [18]. Using more conventional spectroscopic tools, similar problems are addressed in the papers by William F DeGrado, a close collaborator of Robin, and by Sudipta Maiti and Joël Friedman, both former co-workers of Robin.

Time-resolved vibrational spectroscopy on biological systems played an important role in Robin's science even before the invention of 2D IR spectroscopy. A landmark paper in this regard as early as 1989 showed by femtosecond transient IR spectroscopy of the photon induced disappearance of the Fe-CO bond in hemoglobin that the bond breaking is faster than $200 \mathrm{fs}$ [215]. The first author of that paper, Philip Anfinrud, continues to work on related questions, now with very elegant time resolved x-ray diffraction experiments. Furthermore, Manho Lim, a postdoc with Robin, investigates the vibrational relaxation of NO stretching modes in ferrous NO and ferric NO in a model heme.

Robin was always intrigued by the chemical selectivity of vibrational spectroscopy. In combination with the intrinsic high timeresolution, this allows one to investigate ultrafast structural processes in great detail. Such experiments require a fast trigger to initiate a structural transition. In 1997, Robin was the first to introduce the idea of using a photochemical reaction, in this case the light-triggered photodissociation of a disulfide bridge, as a trigger to initiate $\alpha$-helix folding [125]. In their papers, Martin 
Volk and Peter Hamm, both former postdocs with Robin, follow up on that idea and use ultrafast temperature or pH-jumps, respectively, to induce the folding of model $\alpha$-helical peptide polyglutamic acid. The response of the peptide is monitored by transient IR spectroscopy. Similarly, his next-door colleague Feng Gai uses temperature jumps in connection with $\mathrm{D}$-amino acids to delineate the folding mechanism of the Trp-cage.

To understand vibrational energy flow on a more fundamental level, Robin studied the ultrafast vibrational energy relaxation in small molecules and ions, work which has had lasting influence on the experimental and theoretical growth of this field $[196,299]$. Jeffrey Owrutsky and Ted Heilweil were the PhD students responsible for that work, and report on a related problem in their paper.

Robin always combined experimental virtuosity with deep theoretical analysis. One of the intriguing aspects of all of the experiments described so far is the fact that the timescale of the investigated phenomena and size of the molecular system very well match what can be reached with molecular dynamics (MD) simulations, which in turn can provide a very detailed atomistic picture and thus much insight into the processes. Gnana Gnanakaran was a $\mathrm{PhD}$ student of Robin working on simulations, and he continues to be successful with molecular dynamics work, as documented in his paper, where he discusses how Bayesian statistics can deduce the conformational variability of intrinsically disordered proteins from infrared spectroscopy. Many of Robin's theory colleagues at University of Pennsylvania are represented as well. Michael Klein determines the proton affinity of the histidine-tryptophan cluster motif from the influenza A virus from ab initio molecular dynamics, Gregory Voth develops coarse-grained models of proteins based on elastic network, and Andrew Rappe studies the picosecond phenol migration in phenylacetylene solution.

While most of the more recent work of Robin emphasized the 
dynamics of molecular systems on electronic ground state potential energy surface, there are, of course, also important biological processes that involve electronically excited states. The photodissociation of Fe-CO bond in haemoglobin [215] or the photoisomerization of retinal in bacteriorhodopsin [148] are just two examples from Robin's lab. Many of his former co-workers study a wide spread of similar processes, such as the paper of Angus John Bain on the activated barrier crossing dynamics in the nonradiative decay of $\mathrm{NADH}$ and $\mathrm{NADPH}$, that of Bernhard Dick on the electronic spectroscopy to lumiflavin in superfluid helium nanodroplets, that of Chong Fang on the excited-state proton transfer of photoexcited pyranine in water by femtosecond stimulated Raman spectroscopy, and that of Roseanne Sension on the use of broadband ultrafast transient absorption to investigate $\mathrm{Fe}(\mathrm{III}) \mathrm{TPPCl}$ in the condensed phase.

In the late 90's, Robin also developed a strong research line on single molecule spectroscopy, next to the ultrafast work that dominated the group'activity at that time. He was the first to measure by single-molecule confocal microscopy the folding and unfolding conformational equilibrium distributions and dynamics of protein immobilized on a surface [97]. Along the same lines, Bill Eaton, former PhD student and close friend of Robin, measures ultrafast protein folding rates from photon-by-photon analysis of single molecule fluorescence trajectory. Carey Johnson, former postdoc with Robin, analyses single molecule FRET burst measurements by Bayesian nested sampling.

In 1985, Robin, together with graduate student Minyung Lee, was one of the first to observe the long sought-after "Kramers turnover" in the isomerization rate constant as a function of pressure, density and viscosity using supercritical ethane as solvent [262]. In his paper, Minyung Lee again works with photoisomerizing dyes, now as tool to determine the elastic modulus of poly(ethylene oxide).

In the 60's and 70's, Robins research focused on the spectroscopy 
of molecular crystals, where the coupling between molecules leads to excitonic states, a phenomenon which had seen a revival in his work much later when studying the amide I of peptides and proteins [117]. An important topic at that time were ultrahigh magnetic field Zeeman effects in triplet states and the electric field induced Stark effects on molecular excitons [447]. Tom Lin, co-author in that paper, continued along these lines and discusses the dynamics of nuclear polarization by optical pumping in zerofield. Already in these early days, Robin realized that the dimensionality of the molecular crystal has dramatic effect on the spectroscopy [412]. This idea forms the basis of the very active field of nanomaterials spectroscopy. Many of Robin's former coworkers are extremely active in this area now. For example, Bruce Weisman, discusses the length-dependent optical properties of single-walled carbon nanotube samples, Tim Lian, his successor as editor for Chemical Physics, the vibrational relaxation dynamics of catalysts on rutile $\mathrm{TiO}_{2}$ (110) surfaces, Anne Myers Kelley the resonance Raman spectra of wurtzite and zincblende CdSe nanocrystals, and Barry Dellinger the formation of environmentally persistent free radicals from phenol adsorption on $\mathrm{Al}_{2} \mathrm{O}_{3}$ and $\mathrm{TiO}_{2}$.

It is hard to find a topic of Physical Chemistry in which Robin has not been very active. But there are in fact two papers in this Special Issue that deserve that label, namely the paper by Kent Blasie on the structural changes in single membranes in response to an applied transmembrane electric potential revealed by timeresolved neutron and X-ray interferometry, and that of Hai-Lung Dai on the collision-induced intersystem crossing in the ketenyl (HCCO) radical. Both authors were colleagues of Robin at the University of Pennsylvania.

The extraordinary progress in our understanding of condensed phase structure and dynamics over the past 50 years is scarcely conceivable without the massive contributions of Robin Hochstrasser. This volume is a small tribute to that legacy. 


\section{References}

[1] A. Remorino, R. M. Hochstrasser, Three-dimensional structures by twodimensional vibrational spectroscopy, Acc. Chem. Res. 45 (2012) 1896-1905.

[2] M. Abdo, S. P. Brown, J. R. Courter, M. J. Tucker, R. M. Hochstrasser, A. B. Smith, III, Design, synthesis, and photochemical validation of peptide linchpins containing the S,S-tetrazine phototrigger, Organic Letters 14 (2012) $3518-3521$.

[3] M. J. Tucker, M. Abdo, J. R. Courter, J. Chen, A. B. Smith, III, R. M. Hochstrasser, Di-cysteine S,S-tetrazine: A potential ultra-fast photochemical trigger to explore the early events of peptide/protein folding, J. Photochem Photobiol A: Chemistry 234 (2012) 156-163.

[4] C. Falvo, W. Zhuang, Y. S. Kim, P. H. Axelsen, R. M. Hochstrasser, S. Mukamel, Frequency distribution of the amide-I vibration sorted by residues in amyloid fibrils revealed by 2D-IR measurements and simulations, J. Phys. Chem. B 116 (2012) 3322-3330.

[5] D. G. Kuroda, R. M. Hochstrasser, Dynamic structures of aqueous oxalate and the effects of counterions seen by 2D IR, Phys. Chem. Chem. Phys. 14 (2012) 6219-6224.

[6] D. G. Kuroda, R. M. Hochstrasser, Two-dimensional infrared spectral signature and hydration of the oxalate dianion, J. Chem. Phys. 135.

[7] A. Ghosh, R. M. Hochstrasser, A peptide's perspective of water dynamics, Chem. Phys. 390 (2011) 1-13.

[8] A. Ghosh, M. J. Tucker, R. M. Hochstrasser, Identification of arginine residues in peptides by 2D-IR echo spectroscopy, J. Phys. Chem. A 115 (2011) 97319738.

[9] A. Remorino, I. V. Korendovych, Y. Wu, W. F. DeGrado, R. M. Hochstrasser, Residue-specific vibrational echoes yield 3D structures of a transmembrane helix dimer, Science 332 (2011) 1206-1209.

[10] A. Ghosh, J. Qiu, W. F. DeGrado, R. M. Hochstrasser, Tidal surge in the m2 proton channel, sensed by 2D IR spectroscopy, Proc. Natl. Acad. Sci. USA 108 (2011) 6115-6120.

[11] C. Kuo, R. M. Hochstrasser, Super-resolution microscopy of lipid bilayer phases, J. Am. Chem. Soc. 133 (2011) 4664-4667.

[12] M. J. Tucker, X. S. Gai, E. E. Fenlon, S. H. Brewer, R. M. Hochstrasser, 2D IR photon echo of azido-probes for biomolecular dynamics, Phys. Chem. Chem. Phys. 13 (2011) 2237-2241.

[13] D. C. Urbanek, D. Y. Vorobyev, A. L. Serrano, F. Gai, R. M. Hochstrasser, The two-dimensional vibrational echo of a nitrile probe of the villin HP35 protein, J. Phys. Chem. Lett. 1 (2010) 3311-3315. 
[14] D. Y. Vorobyev, C.-H. Kuo, D. G. Kuroda, J. N. Scott, J. M. Vanderkooi, R. M. Hochstrasser, Water-induced relaxation of a degenerate vibration of guanidium using 2d ir echo spectroscopy, J. Phys. Chem. B 114 (2010) 2944-2953.

[15] D. G. Kuroda, D. Y. Vorobyev, R. M. Hochstrasser, Ultrafast relaxation and 2D IR of the aqueous trifluorocarboxylate ion, J. Chem. Phys. 132.

[16] M. J. Tucker, J. R. Courter, J. Chen, O. Atasoylu, A. B. Smith, III, R. M. Hochstrasser, Tetrazine phototriggers: Probes for peptide dynamics, Ang. Chem. Int. Ed. 49 (2010) 3612-3616.

[17] D. Y. Vorobyev, C.-H. Kuo, J.-X. Chen, D. G. Kuroda, J. N. Scott, J. M. Vanderkooi, R. M. Hochstrasser, Ultrafast vibrational spectroscopy of a degenerate mode of guanidinium chloride, J. Phys. Chem. B 113 (2009) 1538215391.

[18] Y. S. Kim, L. Liu, P. H. Axelsen, R. M. Hochstrasser, 2D IR provides evidence for mobile water molecules in beta-amyloid fibrils, Proc. Natl. Acad. Sci. USA 106 (2009) 17751-17756.

[19] S. Bagchi, C. Falvo, S. Mukamel, R. M. Hochstrasser, 2D-IR experiments and simulations of the coupling between amide-I and ionizable side chains in proteins: Application to the villin headpiece, J. Phys. Chem. B 113 (2009) 11260-11273.

[20] Y. S. Kim, R. M. Hochstrasser, Applications of 2D IR spectroscopy to peptides, proteins, and hydrogen-bond dynamics, J. Phys. Chem. B 113 (2009) 82318251.

[21] S. Bagchi, A. K. Charnley, A. B. Smith, III, R. M. Hochstrasser, Equilibrium exchange processes of the aqueous tryptophan dipeptide, J. Phys. Chem. B 113 (2009) 8412-8417.

[22] M. J. Tucker, Y. S. Kim, R. M. Hochstrasser, 2D IR photon echo study of the anharmonic coupling in the ocn region of phenyl cyanate, Chem. Phys. Lett. 470 (2009) 80-84.

[23] A. Ghosh, A. Remorino, M. J. Tucker, R. M. Hochstrasser, 2D IR photon echo spectroscopy reveals hydrogen bond dynamics of aromatic nitriles, Chem. Phys. Lett. 469 (2009) 325-330.

[24] O. S. Finikova, A. Y. Lebedev, A. Aprelev, T. Troxler, F. Gao, C. Garnacho, S. Muro, R. M. Hochstrasser, S. A. Vinogradov, Oxygen microscopy by twophoton-excited phosphorescence, ChemPhysChem 9 (2008) 1673-1679.

[25] Y. S. Kim, L. Liu, P. H. Axelsen, R. M. Hochstrasser, Two-dimensional infrared spectra of isotopically diluted amyloid fibrils from a beta 40, Proc. Natl. Acad. Sci. USA 105 (2008) 7720-7725.

[26] A. Sharonov, R. Bandichhor, K. Burgess, A. D. Petrescu, F. Schroeder, A. B. Kier, R. M. Hochstrasser, Lipid diffusion from single molecules of a labeled protein undergoing dynamic association with giant unilamellar vesicles and supported bilayers, Langmuir 24 (2008) 844-850. 
[27] C. Fang, J. D. Bauman, K. Das, A. Remorino, E. Arnold, R. M. Hochstrasser, Two-dimensional infrared spectra reveal relaxation of the nonnucleoside inhibitor TMC278 complexed with HIV-1 reverse transcriptase, Proc. Natl. Acad. Sci. USA 105 (2008) 1472-1477.

[28] C.-H. Kuo, D. Y. Vorobyev, J. Chen, R. M. Hochstrasser, Correlation of the vibrations of the aqueous azide ion with the $\mathrm{O}-\mathrm{H}$ modes of bound water molecules, J. Phys. Chem. B 111 (2007) 14028-14033.

[29] C.-H. Kuo, R. M. Hochstrasser, Two dimensional infrared spectroscopy and relaxation of aqueous cyanide, Chem. Phys. 341 (2007) 21-28.

[30] R. M. Hochstrasser, Multidimensional ultrafast spectroscopy, Proc. Natl. Acad. Sci. USA 104 (2007) 14189.

[31] R. M. Hochstrasser, Two-dimensional spectroscopy at infrared and optical frequencies, Proc. Natl. Acad. Sci. USA 104 (2007) 14190-14196.

[32] Y. S. Kim, R. M. Hochstrasser, The 2D IR responses of amide and carbonyl modes in water cannot be described by Gaussian frequency fluctuations, J. Phys. Chem. B 111 (2007) 9697-9701.

[33] O. S. Finikova, T. Troxler, A. Senes, W. F. DeGrado, R. M. Hochstrasser, S. A. Vinogradov, Energy and electron transfer in enhanced two-photon-absorbing systems with triplet cores, J. Phys. Chem. A 111 (2007) 6977-6990.

[34] A. Sharonov, R. M. Hochstrasser, Single-molecule imaging of the association of the cell-penetrating peptide Pep- 1 to model membranes, Biochemistry 46 (2007) 7963-7972.

[35] S. Bagchi, Y. S. Kim, A. K. Charnley, A. B. Smith, III, R. M. Hochstrasser, Two-dimensional infrared investigation of $\mathrm{N}$-acetyl tryptophan methyl amide in solution, J. Phys. Chem. B 111 (2007) 3010-3018.

[36] E. Mei, R. M. Hochstrasser, High-resolution optical imaging from trajectory time distributions, J. Phys. Chem. B 110 (2006) 25101-25107.

[37] A. Sharonov, R. M. Hochstrasser, Wide-field subdiffraction imaging by accumulated binding of diffusing probes, Proc. Natl. Acad. Sci. USA 103 (2006) 18911-18916.

[38] K. Kumar, L. E. Sinks, J. Wang, Y. S. Kim, R. M. Hochstrasser, Coupling between $\mathrm{C}-\mathrm{D}$ and $\mathrm{C}=\mathrm{O}$ motions using dual-frequency 2D IR photon echo spectroscopy, Chem. Phys. Lett. 432 (2006) 122-127.

[39] C. Fang, A. Senes, L. Cristian, W. F. DeGrado, R. M. Hochstrasser, Amide vibrations are delocalized across the hydrophobic interface of a transmembrane helix dimer, Proc. Natl. Acad. Sci. USA 103 (2006) 16740-16745.

[40] G.-S. Jiao, L. H. Thoresen, T. G. Kim, W. C. Haaland, F. Gao, M. R. Topp, R. M. Hochstrasser, M. L. Metzker, K. Burgess, Syntheses, photophysical properties, and application of through-bond energy-transfer cassettes for biotechnology, Chem. Eur. J. 12 (2006) 7816-7826. 
[41] C. H. Londergan, J. P. Wang, P. H. Axelsen, R. M. Hochstrasser, Twodimensional infrared spectroscopy displays signatures of structural ordering in peptide aggregates, Biophys. J. 90 (2006) 4672-4685.

[42] Y. S. Kim, R. M. Hochstrasser, Comparison of linear and 2D IR spectra in the presence of fast exchange, J. Phys. Chem. B 110 (2006) 8531-8534.

[43] J. P. Wang, J. X. Chen, R. M. Hochstrasser, Local structure of beta-hairpin isotopomers by FTIR, 2D IR, and ab initio theory, J. Phys. Chem. B 110 (2006) 7545-7555.

[44] F. Gao, E. W. Mei, M. Lim, R. M. Hochstrasser, Probing lipid vesicles by bimolecular association and dissociation trajectories of single molecules, J. Am. Chem. Soc. 128 (2006) 4814-4822.

[45] J. Park, R. M. Hochstrasser, Multidimensional infrared spectroscopy of a peptide intramolecular hydrogen bond, Chem. Phys. 323 (2006) 78-86.

[46] J. P. Wang, R. M. Hochstrasser, Anharmonicity of amide modes, J. Phys. Chem. B 110 (2006) 3798-3807.

[47] J. H. Ha, Y. S. Kim, R. M. Hochstrasser, Vibrational dynamics of N-H, C-D, and $\mathrm{C}=\mathrm{O}$ modes in formamide, J. Chem. Phys. 124.

[48] C. D. Krause, E. W. Mei, O. Mirochnitchenko, N. Lavnikova, J. X. Xie, Y. W. Jia, R. M. Hochstrasser, S. Pestka, Interactions among the components of the interleukin-10 receptor complex, Biochem. Biophys. Res. Commun. 340 (2006) $377-385$.

[49] T. G. Kim, J. C. Castro, A. Loudet, J. G. S. Jiao, R. M. Hochstrasser, K. Burgess, M. R. Topp, Correlations of structure and rates of energy transfer for through-bond energy-transfer cassettes, J. Phys. Chem. A 110 (2006) 2027 .

[50] R. M. Hochstrasser, On a research rollercoaster with friends, Annu. Rev. Phys. Chem. 57 (2006) 37-64.

[51] C. D. Krause, N. Lavnikova, J. X. Xie, E. Mei, O. V. Mirochnitchenko, Y. W. Jia, R. M. Hochstrasser, S. Pestka, Preassembly and ligand-induced restructuring of the chains of the IFN-gamma receptor complex: the roles of Jak kinases, Stat1 and the receptor chains, Cell Research 16 (2006) 55-69.

[52] E. Mei, F. Gao, R. M. Hochstrasser, Controlled bimolecular collisions allow sub-diffraction limited microscopy of lipid vesicles, Phys. Chem. Chem. Phys. 8 (2006) 2077-2082.

[53] C. Fang, R. M. Hochstrasser, Two-dimensional infrared spectra of the ${ }^{13} \mathrm{C}^{18} \mathrm{O}$ isotopomers of alanine residues in an alpha-helix, J. Phys. Chem. B 109 (2005) $18652-18663$.

[54] R. P. Brinas, T. Troxler, R. M. Hochstrasser, S. A. Vinogradov, Phosphorescent oxygen sensor with dendritic protection and two-photon absorbing antenna, J. Am. Chem. Soc. 127 (2005) 11851-11862. 
[55] Y. S. Kim, R. M. Hochstrasser, Chemical exchange 2D IR of hydrogen-bond making and breaking, Proc. Natl. Acad. Sci. USA 102 (2005) 11185-11190.

[56] C. H. Londergan, Y. S. Kim, R. M. Hochstrasser, Two-dimensional infrared spectroscopy of dipeptides in trehalose glass, Mol. Phys. 103 (2005) 1547-1553.

[57] Y. S. Kim, J. P. Wang, R. M. Hochstrasser, Two-dimensional infrared spectroscopy of the alanine dipeptide in aqueous solution, J. Phys. Chem. B 109 (2005) 7511-7521.

[58] Y. S. Kim, R. M. Hochstrasser, Dynamics of amide-I modes of the alanine dipeptide in $\mathrm{D}_{2} \mathrm{O}$, J. Phys. Chem. B 109 (2005) 6884-6891.

[59] R. M. Hochstrasser, Techniques - spectroscopy at a stretch, Nature 434 (2005) $570-571$.

[60] I. V. Rubtsov, K. Kumar, R. M. Hochstrasser, Dual-frequency 2D IR photon echo of a hydrogen bond, Chem. Phys. Lett. 402 (2005) 439-443.

[61] R. M. Hochstrasser, J. R. Norris, S. Mukamel, Gerald james small - obituary, Physics Today 58 (2005) 87.

[62] E. Mei, A. Sharonov, J. H. Ferris, R. M. Hochstrasser, Direct visualization of nanopatterns by single-molecule imaging, Appl. Phys. Lett 86.

[63] E. W. Mei, F. Gao, S. Vinogradov, J. M. Vanderkooi, R. M. Hochstrasser, Phosphorescence of individual horseradish peroxidases proteins having a modified heme group, Chem. Phys. Lett. 401 (2005) 30-34.

[64] J. Park, J. H. Ha, R. M. Hochstrasser, Multidimensional infrared spectroscopy of the N-H bond motions in formamide, J. Chem. Phys. 121 (2004) 7281-7292.

[65] J. Y. Tang, E. Mei, C. Green, J. Kaplan, W. F. DeGrado, A. B. Smith, R. M. Hochstrasser, Probing structural dynamics of individual calmodulin : Peptide complexes in hydrogels by single-molecule confocal microscopy, J. Phys. Chem. B 108 (2004) 15910-15918.

[66] R. M. Hochstrasser, J. R. Norris, S. Mukamel, Gerald small festschrift biography and contributions, J. Phys. Chem. B 108 (2004) 10197-10212.

[67] C. Fang, J. Wang, Y. S. Kim, A. K. Charnley, W. Barber-Armstrong, A. B. Smith, S. M. Decatur, R. M. Hochstrasser, Two-dimensional infrared spectroscopy of isotopomers of an alanine rich alpha-helix, J. Phys. Chem. B 108 (2004) 10415-10427.

[68] S. Gnanakaran, R. M. Hochstrasser, A. E. Garcia, Nature of structural inhomogeneities on folding a helix and their influence on spectral measurements, Proc. Natl. Acad. Sci. USA 101 (2004) 9229-9234.

[69] C. Paul, J. Wang, W. C. Wimley, R. M. Hochstrasser, P. Axelsen, Vibrational coupling, isotopic editing, and beta-sheet structure in a membrane-bound polypeptide, J. Am. Chem. Soc. 126 (2004) 5843-5850. 
[70] I. V. Rubtsov, N. P. Redmore, R. M. Hochstrasser, M. J. Therien, Interrogating conformationally dependent electron-transfer dynamics via ultrafast visible pump/IR probe spectroscopy, J. Am. Chem. Soc. 126 (2004) 2684-2685.

[71] J. P. Wang, R. M. Hochstrasser, Characteristics of the two-dimensional infrared spectroscopy of helices from approximate simulations and analytic models, Chem. Phys. 297 (2004) 195-219.

[72] I. V. Rubtsov, Y. S. Kim, R. M. Hochstrasser, Dynamical models in the twodimensional infrared spectroscopy of peptides, Isr. J. Chem. 44 (2004) 271-280.

[73] C. Fang, J. Wang, A. K. Charnley, W. Barber-Armstrong, A. B. Smith, S. M. Decatur, R. M. Hochstrasser, Two-dimensional infrared measurements of the coupling between amide modes of an alpha-helix, Chem. Phys. Lett. 382 (2003) $586-592$.

[74] J. X. Chen, J. Park, R. M. Hochstrasser, Nonlinear-infrared responses of the $\mathrm{N}-\mathrm{H}$ mode of pyrrole in carbon tetrachloride by heterodyned and stimulated echoes, J. Phys. Chem. A 107 (2003) 10660-10666.

[75] E. W. Mei, S. Vinogradov, R. M. Hochstrasser, Direct observation of triplet state emission of single molecules: Single molecule phosphorescence quenching of metalloporphyrin and organometallic complexes by molecular oxygen and their quenching rate distributions, J. Am. Chem. Soc. 125 (2003) 13198-13204.

[76] C. W. Wan, A. Burghart, J. Chen, F. Bergstrom, L. B. A. Johansson, M. F. Wolford, T. G. Kim, M. R. Topp, R. M. Hochstrasser, K. Burgess, Anthracenebodipy cassettes: Syntheses and energy transfer, Chem. Eur. J. 9 (2003) 44304441.

[77] I. V. Rubtsov, J. P. Wang, R. M. Hochstrasser, Dual-frequency 2D-IR spectroscopy heterodyned photon echo of the peptide bond, Proc. Natl. Acad. Sci. USA 100 (2003) 5601-5606.

[78] I. V. Rubtsov, J. P. Wang, R. M. Hochstrasser, Vibrational coupling between amide-I and amide-A modes revealed by femtosecond two color infrared spectroseopy, J. Phys. Chem. A 107 (2003) 3384-3396.

[79] I. V. Rubtsov, J. Wang, R. M. Hochstrasser, Dual frequency 2D-IR of peptide amide-A and amide-I modes, J. Chem. Phys. 118 (2003) 7733-7736.

[80] E. Mei, J. Y. Tang, J. M. Vanderkooi, R. M. Hochstrasser, Motions of single molecules and proteins in trehalose glass, J. Am. Chem. Soc. 125 (2003) 27302735 .

[81] C. D. Krause, E. Mei, J. X. Xie, Y. W. Jia, M. A. Bopp, R. M. Hochstrasser, S. Pestka, Seeing the light - preassembly and ligand-induced changes of the interferon gamma receptor complex in cells, Mol. Cell. Proteomics 1 (2002) 805-815.

[82] I. V. Rubtsov, R. M. Hochstrasser, Vibrational dynamics, mode coupling, and structural constraints for acetylproline- $\mathrm{NH}_{2}$, J. Phys. Chem. B 106 (2002) 9165-9171. 
[83] M. Lee, J. Kim, J. Tang, R. M. Hochstrasser, Fluorescence quenching and lifetime distributions of single molecules on glass surfaces, Chem. Phys. Lett. 359 (2002) 412-419.

[84] R. M. Hochstrasser, N. H. Ge, S. Gnanakaran, M. T. Zanni, Two dimensional infrared spectroscopy: Studies of the dynamics of structures with femtosecond pulse fourier transform correlation spectroscopy, Bull. Chem. Soc. Jpn. 75 (2002) 1103-1110.

[85] N. H. Ge, M. T. Zanni, R. M. Hochstrasser, Effects of vibrational frequency correlations on two-dimensional infrared spectra, J. Phys. Chem. A 106 (2002) 962-972.

[86] N. H. Ge, R. M. Hochstrasser, Femtosecond two-dimensional infrared spectroscopy: IR-COSY and THIRSTY, Phys. Chem. Comm. 5 (2002) 1726.

[87] S. Gnanakaran, R. M. Hochstrasser, Conformational preferences and vibrational frequency distributions of short peptides in relation to multidimensional infrared spectroscopy, J. Am. Chem. Soc. 123 (2001) 1288612898.

[88] M. Lim, R. M. Hochstrasser, Unusual vibrational dynamics of the acetic acid dimer, J. Chem. Phys. 115 (2001) 7629-7643.

[89] M. T. Zanni, R. M. Hochstrasser, Two-dimensional infrared spectroscopy: a promising new method for the time resolution of structures, Curr. Opin. Struc. Biol. 11 (2001) 516-522.

[90] M. T. Zanni, N. H. Ge, Y. S. Kim, R. M. Hochstrasser, Two-dimensional IR spectroscopy can be designed to eliminate the diagonal peaks and expose only the crosspeaks needed for structure determination, Proc. Natl. Acad. Sci. USA 98 (2001) 11265-11270.

[91] R. Kumble, T. D. Howard, R. J. Cogdell, R. M. Hochstrasser, Dynamic infrared band-band spectroscopy of peripheral light-harvesting complexes from R-acidophila, J. Photochem. Photobiol., A 142 (2001) 121-126.

[92] M. Lee, J. Y. Tang, R. M. Hochstrasser, Fluorescence lifetime distribution of single molecules undergoing forster energy transfer, Chem. Phys. Lett. 344 (2001) 501-508.

[93] M. T. Zanni, S. Gnanakaran, J. Stenger, R. M. Hochstrasser, Heterodyned two-dimensional infrared spectroscopy of solvent-dependent conformations of acetylproline- $\mathrm{NH}_{2}$, J. Phys. Chem. B 105 (2001) 6520-6535.

[94] M. C. Asplund, M. Lim, R. M. Hochstrasser, Spectrally resolved three pulse photon echoes in the vibrational infrared (vol 323, pg 269, 2000), Chem. Phys. Lett. 340 (2001) 611.

[95] R. M. Hochstrasser, Two-dimensional IR-spectroscopy: polarization anisotropy effects, Chem. Phys. 266 (2001) 273-284. 
[96] M. T. Zanni, M. C. Asplund, R. M. Hochstrasser, Two-dimensional heterodyned and stimulated infrared photon echoes of N-methylacetamide-D, J. Chem. Phys. 114 (2001) 4579-4590.

[97] D. S. Talaga, W. L. Lau, H. Roder, J. Y. Tang, Y. W. Jia, W. F. DeGrado, R. M. Hochstrasser, Dynamics and folding of single two-stranded coiled-coil peptides studied by fluorescent energy transfer confocal microscopy, Proc. Natl. Acad. Sci. USA 97 (2000) 13021-13026.

[98] P. Changenet-Barret, C. T. Choma, E. F. Gooding, W. F. DeGrado, R. M. Hochstrasser, Ultrafast dielectric response of proteins from dynamics Stokes shifting of coumarin in calmodulin, J. Phys. Chem. B 104 (2000) 9322-9329.

[99] Y. Kholodenko, M. Volk, E. Gooding, R. M. Hochstrasser, Energy dissipation and relaxation processes in deoxy myoglobin after photoexcitation in the Soret region, Chem. Phys. 259 (2000) 71-87.

[100] D. J. Cook, R. M. Hochstrasser, Intense terahertz pulses by four-wave rectification in air, Opt. Lett. 25 (2000) 1210-1212.

[101] M. C. Asplund, M. T. Zanni, R. M. Hochstrasser, Two-dimensional infrared spectroscopy of peptides by phase-controlled femtosecond vibrational photon echoes, Proc. Natl. Acad. Sci. USA 97 (2000) 8219-8224.

[102] M. C. Asplund, M. Lim, R. M. Hochstrasser, Spectrally resolved three pulse photon echoes in the vibrational infrared, Chem. Phys. Lett. 323 (2000) 269277.

[103] P. Hamm, M. Lim, W. F. DeGrado, R. M. Hochstrasser, Pump/probe self heterodyned 2D spectroscopy of vibrational transitions of a small globular peptide, J. Chem. Phys. 112 (2000) 1907-1916.

[104] P. Hamm, M. Lim, W. F. DeGrado, R. M. Hochstrasser, Stimulated photon echoes from amide I vibrations, J. Phys. Chem. A 103 (1999) 10049-10053.

[105] M. A. Bopp, A. Sytnik, T. D. Howard, R. J. Cogdell, R. M. Hochstrasser, The dynamics of structural deformations of immobilized single light-harvesting complexes, Proc. Natl. Acad. Sci. USA 96 (1999) 11271-11276.

[106] D. J. Cook, J. X. Chen, E. A. Morlino, R. M. Hochstrasser, Terahertz-fieldinduced second-harmonic generation measurements of liquid dynamics, Chem. Phys. Lett. 309 (1999) 221-228.

[107] Y. W. Jia, D. S. Talaga, W. L. Lau, H. S. M. Lu, W. F. DeGrado, R. M. Hochstrasser, Folding dynamics of single gcn4 peptides by fluorescence resonant energy transfer confocal microscopy, Chem. Phys. 247 (1999) 69-83.

[108] Y. Kholodenko, E. A. Gooding, Y. Dou, M. Ikeda-Saito, R. M. Hochstrasser, Heme protein dynamics revealed by geminate nitric oxide recombination in mutants of iron and cobalt myoglobin, Biochemistry 38 (1999) 5918-5924.

[109] S. Gnanakaran, R. M. Hochstrasser, Effect of vibrational coherence on rotational dynamics in solution, Int. J. Quantum Chemistry 72 (1999) 451-462. 
[110] G. Haran, E. A. Morlino, J. Matthes, R. H. Callender, R. M. Hochstrasser, Femtosecond polarized pump-probe and stimulated emission spectroscopy of the isomerization reaction of rhodopsin, J. Phys. Chem. A 103 (1999) 22022207.

[111] P. Hamm, M. Lim, W. F. DeGrado, R. M. Hochstrasser, The two-dimensional IR nonlinear spectroscopy of a cyclic penta-peptide in relation to its threedimensional structure, Proc. Natl. Acad. Sci. USA 96 (1999) 2036-2041.

[112] P. Hamm, M. Lim, M. Asplund, R. M. Hochstrasser, The fifth-order contribution to the oscillations in photon echoes of anharmonic vibrators, Chem. Phys. Lett. 301 (1999) 167-174.

[113] A. Sytnik, S. Vladimirov, Y. W. Jia, L. Q. Li, B. S. Cooperman, R. M. Hochstrasser, Peptidyl transferase center activity observed in single ribosomes, J. Mol. Biol. 285 (1999) 49-54.

[114] M. H. Lim, P. Hamm, R. M. Hochstrasser, Protein fluctuations are sensed by stimulated infrared echoes of the vibrations of carbon monoxide and azide probes, Proc. Natl. Acad. Sci. USA 95 (1998) 15315-15320.

[115] P. Hamm, M. Lim, R. M. Hochstrasser, Non-markovian dynamics of the vibrations of ions in water from femtosecond infrared three-pulse photon echoes, Phys. Rev. Lett. 81 (1998) 5326-5329.

[116] R. Kumble, S. Palese, V. S. Y. Lin, M. J. Therien, R. M. Hochstrasser, Ultrafast dynamics of highly conjugated porphyrin arrays, J. Am. Chem. Soc. 120 (1998) 11489-11498.

[117] P. Hamm, M. H. Lim, R. M. Hochstrasser, Structure of the amide I band of peptides measured by femtosecond nonlinear-infrared spectroscopy, J. Phys. Chem. B 102 (1998) 6123-6138.

[118] R. Kumble, R. M. Hochstrasser, Disorder-induced exciton scattering in the light-harvesting systems of purple bacteria: Influence on the anisotropy of emission and band $->$ band transitions, J. Chem. Phys. 109 (1998) 855865 .

[119] M. A. Bopp, Y. Jia, G. Haran, E. A. Morlino, R. M. Hochstrasser, Singlemolecule spectroscopy with 27 fs pulses: Time-resolved experiments and direct imaging of orientational distributions, Appl. Phys. Lett 73 (1998) 7-9.

[120] M. H. Lim, M. Wolford, P. Hamm, R. M. Hochstrasser, Chirped wavepacket dynamics of hgbr from the photolysis of $\mathrm{HgBr}_{2}$ in solution, Chem. Phys. Lett. 290 (1998) 355-362.

[121] R. M. Hochstrasser, Ultrafast spectroscopy of protein dynamics, J. Chem. Education 75 (1998) 559-564.

[122] S. Gnanakaran, M. Lim, M. Volk, E. Gooding, Y. Kholodenko, R. M. Hochstrasser, Chemical reaction dynamics of some simple molecules in solution, Phil. Trans. R. Soc. A 356 (1998) 377-388. 
[123] P. Hamm, M. Lim, R. M. Hochstrasser, Vibrational energy relaxation of the cyanide ion in water, J. Chem. Phys. 107 (1997) 10523-10531.

[124] G. Haran, W. D. Sun, K. Wynne, R. M. Hochstrasser, Femtosecond far-infrared pump-probe spectroscopy: a new tool for studying low-frequency vibrational dynamics in molecular condensed phases (vol 274, pg 365, 1997), Chem. Phys. Lett. 277 (1997) 579.

[125] M. Volk, Y. Kholodenko, H. S. M. Lu, E. A. Gooding, W. F. DeGrado, R. M. Hochstrasser, Peptide conformational dynamics and vibrational Stark effects following photoinitiated disulfide cleavage, J. Phys. Chem. B 101 (1997) 86078616.

[126] M. A. Bopp, Y. W. Jia, L. Q. Li, R. J. Cogdell, R. M. Hochstrasser, Fluorescence and photobleaching dynamics of single light-harvesting complexes, Proc. Natl. Acad. Sci. USA 94 (1997) 10630-10635.

[127] G. Haran, W. D. Sun, K. Wynne, R. M. Hochstrasser, Femtosecond far-infrared pump-probe spectroscopy: A new tool for studying low-frequency vibrational dynamics in molecular condensed phases, Chem. Phys. Lett. 274 (1997) 365371.

[128] H. S. M. Lu, M. Volk, Y. Kholodenko, E. Gooding, R. M. Hochstrasser, W. F. DeGrado, Aminothiotyrosine disulfide, an optical trigger for initiation of protein folding, J. Am. Chem. Soc. 119 (1997) 7173-7180.

[129] Y. W. Jia, A. Sytnik, L. Q. Li, S. Vladimirov, B. S. Cooperman, R. M. Hochstrasser, Nonexponential kinetics of a single tRNA(Phe) molecule under physiological conditions, Proc. Natl. Acad. Sci. USA 94 (1997) 7932-7936.

[130] M. H. Lim, S. Gnanakaran, R. M. Hochstrasser, Charge shifting in the ultrafast photoreactions of $\mathrm{ClO}^{-}$in water, J. Chem. Phys. 106 (1997) 3485-3493.

[131] M. Volk, S. Gnanakaran, E. Gooding, Y. Kholodenko, N. Pugliano, R. M. Hochstrasser, Anisotropy measurements of solvated $\mathrm{HgI}_{2}$ dissociation: Transition state and fragment rotational dynamics, J. Phys. Chem. A 101 (1997) 638-643.

[132] R. M. Hochstrasser, J. P. Simons, Dynamics of electronically excited states in gaseous, cluster and condensed media - concluding remarks, Faraday Discuss. 108 (1997) 469-471.

[133] N. Pugliano, S. Gnanakaran, R. M. Hochstrasser, The dynamics of photodissociation reactions in solution, J. Photochem. Photobiol., A 102 (1996) 21-28.

[134] J. P. Culver, M. Li, R. M. Hochstrasser, A. G. Yodh, Vibrational dynamics of low frequency $\left(<100 \mathrm{~cm}^{-1}\right)$ adsorbate motions, Surface Science 368 (1996) 9-19.

[135] S. Gnanakaran, M. Lim, N. Pugliano, M. Volk, R. M. Hochstrasser, Energy and phase relaxation accompanying impulsive reactions in liquids, J. Phys.: Condens. Matter 8 (1996) 9201-9220. 
[136] G. Haran, K. Wynne, A. H. Xie, Q. He, M. Chance, R. M. Hochstrasser, Excited state dynamics of bacteriorhodopsin revealed by transient stimulated emission spectra, Chem. Phys. Lett. 261 (1996) 389-395.

[137] R. Kumble, S. Palese, R. W. Visschers, P. L. Dutton, R. M. Hochstrasser, Ultrafast dynamics within the B820 subunit from the core (LH-1) antenna complex of Rs-rubrum, Chem. Phys. Lett. 261 (1996) 396-404.

[138] S. Gnanakaran, R. M. Hochstrasser, Vibrational relaxation of HgI in ethanol: Equilibrium molecular dynamics simulations, J. Chem. Phys. 105 (1996) 34863496.

[139] K. Wynne, G. D. Reid, R. M. Hochstrasser, Vibrational coherence in electron transfer: The tetracyanoethylene-pyrene complex, J. Chem. Phys. 105 (1996) $2287-2297$.

[140] G. A. Voth, R. M. Hochstrasser, Transition state dynamics and relaxation processes in solutions: A frontier of physical chemistry, J. Phys. Chem. 100 (1996) 13034-13049.

[141] J. P. Culver, M. Li, Z. J. Sun, R. M. Hochstrasser, A. G. Yodh, Temperaturedependent coupling of low frequency adsorbate vibrations to metal substrate electrons, Chem. Phys. 205 (1996) 159-166.

[142] N. Pugliano, A. Z. Szarka, R. M. Hochstrasser, Relaxation of the product state coherence generated through the photolysis of $\mathrm{HgI}_{2}$ in solution, J. Chem. Phys. 104 (1996) 5062-5079.

[143] G. Haran, K. Wynne, C. C. Moser, P. L. Dutton, R. M. Hochstrasser, Level mixing and energy redistribution in bacterial photosynthetic reaction centers, J. Phys. Chem. 100 (1996) 5562-5569.

[144] K. Wynne, G. Haran, G. D. Reid, C. C. Moser, P. L. Dutton, R. M. Hochstrasser, Femtosecond infrared spectroscopy of low-lying excited states in reaction centers of rhodobacter sphaeroides, J. Phys. Chem. 100 (1996) $5140-5148$.

[145] N. Pugliano, A. Z. Szarka, S. Gnanakaran, M. Triechel, R. M. Hochstrasser, Vibrational population-dynamics of the $\mathrm{HgI}$ photofragment in ethanol solution, J. Chem. Phys. 103 (1995) 6498-6511.

[146] C. C. Moser, R. J. Sension, A. Z. Szarka, S. T. Repinic, R. M. Hochstrasser, P. L. Dutton, Initial charge separation kinetics of bacterial photosynthetic reaction centers in oriented Langmuir-Blodgett-films in an applied electricfield, Chem. Phys. 197 (1995) 343-354.

[147] C. M. Phillips, Y. Mizutani, R. M. Hochstrasser, Ultrafast thermally-induced unfolding of rNASE-A, Proc. Natl. Acad. Sci. USA 92 (1995) 7292-7296.

[148] R. Diller, S. Maiti, G. C. Walker, B. R. Cowen, R. Pippenger, R. A. Bogomolni, R. M. Hochstrasser, Femtosecond time-resolved infrared-laser study of the J-K transition of bacteriorhodopsin, Chem. Phys. Lett. 241 (1995) 109-115. 
[149] K. Wynne, R. M. Hochstrasser, Anisotropy as an ultrafast probe of electronic coherence in degenerate systems exhibiting Raman-scattering, fluorescence, transient absorption and chemical-reactions, J. Raman Spectrosc. 26 (1995) $561-569$.

[150] A. Z. Szarka, N. Pugliano, D. K. Palit, R. M. Hochstrasser, Vibrational coherence in the solution-phase photoisomerization reaction of cis-stilbene, Chem. Phys. Lett. 240 (1995) 25-30.

[151] T. Q. Lian, Y. Kholodenko, B. Locke, R. M. Hochstrasser, 3rd-Order nonlinearities studied by femtosecond infrared methods, J. Phys. Chem. 99 (1995) 7272-7280.

[152] K. Wynne, R. M. Hochstrasser, The theory of ultrafast vibrational spectroscopy, Chem. Phys. 193 (1995) 211-236.

[153] K. Wynne, S. M. Lecours, C. Galli, M. J. Therien, R. M. Hochstrasser, Porphyrin-quinone electron-transfer revisited - the role of excited-state degeneracy in ultrafast charge-transfer reactions, J. Am. Chem. Soc. 117 (1995) 3749-3753.

[154] J. C. Owrutsky, M. Li, B. Locke, R. M. Hochstrasser, Vibrational-relaxation of the $\mathrm{CO}$ stretch vibration in hemoglobin-CO, myoglobin- $\mathrm{CO}$, and protohemeCO, J. Phys. Chem. 99 (1995) 4842-4846.

[155] T. Q. Lian, Y. Kholodenko, R. M. Hochstrasser, Infrared probe of the solvent response to ultrafast solvation processes, J. Phys. Chem. 99 (1995) 2546-2551.

[156] B. Locke, T. Lian, R. M. Hochstrasser, Determination of FE-CO geometry and heme rigidity in carbonmonoxyhemoglobin using femtosecond IR spectroscopy (vol 158, pg 409, 1991), Chem. Phys. 190 (1995) 155.

[157] D. Raftery, E. Gooding, A. Romanovsky, R. M. Hochstrasser, Vibrational product state dynamics in solution-phase bimolecular reactions - transient infrared study of CN radical reactions, J. Chem. Phys. 101 (1994) 8572-8579.

[158] T. Q. Lian, B. Locke, Y. Kholodenko, R. M. Hochstrasser, Energy-flow from solute to solvent probed by femtosecond IR spectroscopy - malachite green and heme protein solutions, J. Phys. Chem. 98 (1994) 11648-11656.

[159] S. Maiti, G. C. Walker, B. R. Cowen, R. Pippenger, C. C. Moser, P. L. DUTTON, R. M. Hochstrasser, Femtosecond coherent transient infraredspectroscopy of reaction centers from rhodobacter-sphaeroides, Proc. Natl. Acad. Sci. USA 91 (1994) 10360-10364.

[160] D. A. M. Smith, S. A. Williams, P. Jenkner, R. D. Miller, E. J. Ginsburg, R. M. Hochstrasser, Localization of excitations by electrondonating side-groups in the novel copolymer poly[methylphenyl-CO-methyl4-(dimethylamino)phenylsilane], J. Phys. Chem. 98 (1994) 7359-7365.

[161] K. Wynne, G. D. Reid, R. M. Hochstrasser, Regenerative amplification of 30-fs pulses in Ti-sapphire at $5 \mathrm{kHz}$, Opt. Lett. 19 (1994) 895-897. 
[162] G. C. Walker, S. Maiti, B. R. Cowen, C. C. Moser, P. L. Dutton, R. M. Hochstrasser, Time resolution of electronic-transitions of photosynthetic reaction centers in the infrared, J. Phys. Chem. 98 (1994) 5778-5783.

[163] K. Wynne, C. Galli, R. M. Hochstrasser, Ultrafast charge-transfer in an electron donor-acceptor complex, J. Chem. Phys. 100 (1994) 4797-4810.

[164] K. Wynne, S. Gnanakaran, C. Galli, F. Zhu, R. M. Hochstrasser, Luminescence studies of ultrafast energy-transfer oscillations in dimers, J. Lumin. 60-1 (1994) $735-738$.

[165] P. G. Smith, S. Gnanakaran, A. J. Kaziska, A. L. Motyka, S. M. Hong, R. M. Hochstrasser, M. R. Topp, Electronic coupling and conformational barrier crossing of 9,9'-bifluorenyl studied in a supersonic jet, J. Chem. Phys. 100 (1994) 3384-3393.

[166] J. C. Owrutsky, D. Raftery, R. M. Hochstrasser, Vibrational-relaxation dynamics in solutions, Annu. Rev. Phys. Chem. 45 (1994) 519-555.

[167] J. P. Culver, M. LI, L. G. Jahn, R. M. Hochstrasser, A. G. Yodh, Vibrational response of surface adsorbates to femtosecond substrate heating, Chem. Phys. Lett. 214 (1993) 431-437.

[168] N. Pugliano, D. K. Palit, A. Z. Szarka, R. M. Hochstrasser, Wave-packet dynamics of the $\mathrm{HgI}_{2}$ photodissociation reaction in solution, J. Chem. Phys. 99 (1993) $7273-7276$.

[169] K. Wynne, R. M. Hochstrasser, Coherence effects in the anisotropy of optical experiments (vol 171, pg 179, 1993), Chem. Phys. 173 (1993) 539.

[170] T. Lian, B. Locke, T. Kitagawa, M. Nagai, R. M. Hochstrasser, Determination of FE-CO geometry in the subunits of carbonmonoxyhemoglobin $\mathrm{m}$ boston using femtosecond infrared-spectroscopy, Biochemistry 32 (1993) 5809-5814.

[171] F. Zhu, C. Galli, R. M. Hochstrasser, The real-time intramolecular electronic excitation transfer dynamics of 9',9-bifluorene and 2',2-binaphthyl in solution (vol 98, pg 1042, 1993), J. Chem. Phys. 98 (1993) 9222.

[172] S. Maiti, B. R. Cowen, R. Diller, M. Iannone, C. C. Moser, P. L. Dutton, R. M. Hochstrasser, Picosecond infrared studies of the dynamics of the photosynthetic reaction center, Proc. Natl. Acad. Sci. USA 90 (1993) 52475251.

[173] C. Galli, K. Wynne, S. M. Lecours, M. J. Therien, R. M. Hochstrasser, Direct measurement of electronic dephasing using anisotropy, Chem. Phys. Lett. 206 (1993) 493-499.

[174] R. J. Sension, S. T. Repinic, A. Z. Szarka, R. M. Hochstrasser, Femtosecond laser studies of the cis-stilbene photoisomerization reactions, J. Chem. Phys. 98 (1993) 6291-6315.

[175] K. Wynne, R. M. Hochstrasser, Coherence effects in the anisotropy of optical experiments, Chem. Phys. 171 (1993) 179-188. 
[176] M. LI, J. Owrutsky, M. Sarisky, J. P. Culver, A. Yodh, R. M. Hochstrasser, Vibrational and rotational relaxation-times of solvated molecular-ions, J. Chem. Phys. 98 (1993) 5499-5507.

[177] R. J. Sension, R. M. Hochstrasser, Rotational friction coefficients for ellipsoids and chemical molecules with slip boundary-conditions - comment, J. Chem. Phys. 98 (1993) 2490.

[178] F. Zhu, C. Galli, R. M. Hochstrasser, The real-time intramolecular electronic excitation transfer dynamics of 9',9-bifluorene and 2',2-binaphthyl in solution, J. Chem. Phys. 98 (1993) 1042-1057.

[179] D. Raftery, M. Iannone, C. M. Phillips, R. M. Hochstrasser, Hydrogen abstraction dynamics in solution studied by picosecond infrared-spectroscopy, Chem. Phys. Lett. 201 (1993) 513-520.

[180] P. Chandrasekhar, J. R. G. Thorne, R. M. Hochstrasser, Structure property relationships in off-resonant 3rd-order nonlinearities of conducting polymers .1. poly(aromatic amines) and ring-s-heteroatom-containing polymers, Synth. Met. 53 (1993) 175-191.

[181] Y. R. Kim, R. M. Hochstrasser, Rotational diffusion of fluorene in hydroxylic solvents, J. Phys. Chem. 96 (1992) 9595-9597.

[182] R. J. Sension, A. Z. Szarka, R. M. Hochstrasser, Vibrational-energy redistribution and relaxation in the photoisomerization of cis-stilbene, J. Chem. Phys. 97 (1992) 5239-5242.

[183] J. C. Owrutsky, J. P. Culver, M. Li, Y. R. Kim, M. J. Sarisky, M. S. Yeganeh, A. G. Yodh, R. M. Hochstrasser, Femtosecond coherent transient infraredspectroscopy of CO on CU(111), J. Chem. Phys. 97 (1992) 4421-4427.

[184] R. H. French, J. S. Meth, J. R. G. Thorne, R. M. Hochstrasser, R. D. Miller, Vacuum ultraviolet spectroscopy of the optical-properties and electronicstructure of 7 poly(di-alkylsilanes), Synth. Met. 50 (1992) 499-508.

[185] J. R. G. Thorne, J. G. Masters, S. A. Williams, A. G. MacDiarmid, R. M. Hochstrasser, Time-resolved fluorescence of polyaniline, Synth. Met. 49 (1992) 159-165.

[186] J. R. G. Thorne, A. Tilgner, Y. R. Kim, J. M. Zeigler, H. P. Trommsdorff, R. M. Hochstrasser, Exciton transfer and dephasing in polysilanes at lowtemperature, J. Lumin. 53 (1992) 170-174.

[187] R. Diller, M. Iannone, B. R. Cowen, S. Maiti, R. A. Bogomolni, R. M. Hochstrasser, Picosecond dynamics of bacteriorhodopsin, probed by timeresolved infrared-spectroscopy, Biochemistry 31 (1992) 5567-5572.

[188] K. Wynne, C. Galli, R. M. Hochstrasser, Femtosecond intermolecular vibrational motion in pyrrole, Chem. Phys. Lett. 193 (1992) 17-22. 
[189] A. Tilgner, H. P. Trommsdorff, J. M. Zeigler, R. M. Hochstrasser, Poly(dinormal-hexyl-silane) in solid-solutions - experimental and theoretical-studies of electronic excitations of a disordered linear-chain, J. Chem. Phys. 96 (1992) 781-796.

[190] J. R. G. Thorne, R. M. Hochstrasser, J. M. Zeigler, A. Tilgner, H. P. Trommsdorff, R. H. French, P. J. Fagan, R. D. Miller, Electronic and vibrational excitations in polysilanes and oligomers, Mol. Cryst. Liq. Cryst. 216-18 (1992) 13-19.

[191] M. Iannone, B. R. Cowen, R. Diller, S. Maiti, R. M. Hochstrasser, Highrepetition-rate infrared-pump, infrared-probe spectrometer, Appl. Opt. 30 (1991) 5247-5249.

[192] B. Locke, T. Lian, R. M. Hochstrasser, Determination of FE-CO geometry and heme rigidity in carbonmonoxyhemoglobin using femtosecond IR spectroscopy, Chem. Phys. 158 (1991) 409-419.

[193] S. T. Repinic, R. J. Sension, A. Z. Szarka, R. M. Hochstrasser, Femtosecond laser studies of the cis-stilbene photoisomerization reactions - the cis-stilbene to dihydrophenanthrene reaction, J. Phys. Chem. 95 (1991) 10380-10385.

[194] J. R. G. Thorne, S. A. Williams, R. M. Hochstrasser, P. J. Fagan, Radiative lifetimes of confined excitations in sigma-conjugated silane oligomers, Chem. Phys. 157 (1991) 401-408.

[195] R. J. Sension, A. Z. Szarka, G. R. Smith, R. M. Hochstrasser, Ultrafast photoinduced electron-transfer to C60, Chem. Phys. Lett. 185 (1991) 179-183.

[196] J. C. Owrutsky, Y. R. Kim, M. LI, M. J. Sarisky, R. M. Hochstrasser, Determination of the vibrational-energy relaxation-time of the azide ion in protic solvents by 2-color transient infrared-spectroscopy, Chem. Phys. Lett. 184 (1991) 368-374.

[197] P. Chandrasekhar, J. R. G. Thorne, R. M. Hochstrasser, 3rd-order nonlinear optical-properties of poly(diphenyl amine) and poly(4-amino biphenyl), novel processible conducting polymers, Appl. Phys. Lett 59 (1991) 1661-1663.

[198] R. J. Sension, C. M. Phillips, A. Z. Szarka, W. J. Romanow, A. R. McGhie, J. P. McCauley, A. B. Smith, R. M. Hochstrasser, Transient absorption studies of C60 in solution, J. Phys. Chem. 95 (1991) 6075-6078.

[199] R. Diller, M. Iannone, R. Bogomolni, R. M. Hochstrasser, Ultrafast infraredspectroscopy of bacteriorhodopsin, Biophysical J. 60 (1991) 286-289.

[200] R. J. Sension, S. T. Repinic, R. M. Hochstrasser, Femtosecond laser study of the alignment of reactant and products in the photoisomerization reactions of cis-stilbene, J. Phys. Chem. 95 (1991) 2946-2948.

[201] S. T. Repinic, R. J. Sension, R. M. Hochstrasser, Femtosecond studies of the photoisomerization of cis-stilbene in solution, Ber. Bunsen-Ges. Phys. Chem. 95 (1991) 248-252. 
[202] R. M. Hochstrasser, M. A. Pereira, P. E. Share, M. J. Sarisky, Y. R. KIM, S. T. Repinic, R. J. Sension, J. R. G. Thorne, M. IANNONE, R. Diller, P. A. Anfinrud, C. Han, T. Lian, B. Locke, Anisotropy studies of ultrafast dipole reorientations, Proc. - Indian Acad. Sci., Chem. Sci. 103 (1991) 351-362.

[203] M. A. Pereira, P. E. Share, M. J. Sarisky, R. M. Hochstrasser, Ultrafast rotational-dynamics of electronically excited aniline molecules in solution from ultraviolet femtosecond fluorescence anisotropies, J. Chem. Phys. 94 (1991) $2513-2522$.

[204] P. A. Anfinrud, C. H. Han, T. Q. Lian, R. M. Hochstrasser, Femtosecond infrared-spectroscopy - ultrafast photochemistry of iron carbonyls in solution, J. Phys. Chem. 95 (1991) 574-578.

[205] A. Tilgner, J. R. G. Thorne, J. P. Pique, J. M. Zeigler, R. M. Hochstrasser, H. P. Trommsdorff, Excited-state dynamics of poly-di-normal-hexyl-silane, J. Lumin. 48-9 (1991) 193-198.

[206] P. Share, M. Pereira, M. Sarisky, S. Repinic, R. M. Hochstrasser, Dynamics of proton-transfer in 7-azaindole, J. Lumin. 48-9 (1991) 204-208.

[207] R. J. Sension, S. T. Repinic, R. M. Hochstrasser, Femtosecond laser study of energy disposal in the solution phase isomerization of stilbene, J. Chem. Phys. 93 (1990) 9185-9188.

[208] J. R. G. Thorne, S. T. Repinic, S. A. Abrash, J. M. Zeigler, R. M. Hochstrasser, Polysilane excited-states and excited-state dynamics, Chem. Phys. 146 (1990) $315-325$.

[209] S. Abrash, S. Repinic, R. M. Hochstrasser, The viscosity dependence and reaction coordinate for isomerization of cis-stilbene, J. Chem. Phys. 93 (1990) 1041-1053.

[210] P. A. Anfinrud, C. Han, T. Lian, R. M. Hochstrasser, Evolution of the transient vibrational-spectrum following short-pulse excitation, J. Phys. Chem. 94 (1990) 1180-1184.

[211] J. R. G. Thorne, Y. Ohsako, S. T. Repinic, S. A. Abrash, J. M. Zeigler, R. M. Hochstrasser, The excited-states of linear-chain polysilanes, J. Lumin. 45 (1990) 295-297.

[212] A. Tilgner, H. P. Trommsdorff, J. M. Zeigler, R. M. Hochstrasser, Excitation dynamics in polysilanes, J. Lumin. 45 (1990) 373-376.

[213] Y. R. Kim, P. Share, M. Pereira, M. Sarisky, R. M. Hochstrasser, Direct measurements of energy-transfer between identical chromophores in solution, J. Chem. Phys. 91 (1989) 7557-7562.

[214] P. J. Carroll, J. N. Haseltine, R. M. Hochstrasser, A. B. Smith, Structures of (E,E)-1,1'-ethanediylidenebis(2,3-dihydro-1H-indene),(E,E)-1,1'ethanedi ylidenebis $(1,2,3,4-$ tetrahydronaphthalene) and (E,E)-5,5'-ethanediylidenebis(6,7,8,9-tetrahydro5H-benzocycloheptene), Acta Crystallogr., Sect. C: Cryst. Struct. Commun. 45 (1989) 1803-1805. 
[215] P. A. Anfinrud, C. Han, R. M. Hochstrasser, Direct observations of ligand dynamics in hemoglobin by subpicosecond infrared-spectroscopy, Proc. Natl. Acad. Sci. USA 86 (1989) 8387-8391.

[216] J. R. G. Thorne, Y. Ohsako, J. M. Zeigler, R. M. Hochstrasser, 2-Photon spectroscopy of polysilanes, Chem. Phys. Lett. 162 (1989) 455-460.

[217] Y. R. Kim, J. T. Yardley, R. M. Hochstrasser, Solvent effects on intramolecular proton-transfer, Chem. Phys. 136 (1989) 311-319.

[218] M. Y. Lee, J. N. Haseltine, A. B. Smith, R. M. Hochstrasser, Isomerization processes of electronically excited stilbene and diphenylbutadiene in liquids are they one-dimensional, J. Am. Chem. Soc. 111 (1989) 5044-5051.

[219] J. N. Moore, P. A. Hansen, R. M. Hochstrasser, Picosecond infrared probing of metal-carbonyl photodissociation products, J. Am. Chem. Soc. 111 (1989) $4563-4566$.

[220] Y. Ohsako, J. R. G. Thorne, C. M. Phillips, J. M. Zeigler, R. M. Hochstrasser, Picosecond transient absorption-spectroscopy of polysilanes, J. Phys. Chem. 93 (1989) 4408-4411.

[221] R. M. Hochstrasser, Biological applications of ultrafast laser methods, Ber. Bunsen-Ges. Phys. Chem. 93 (1989) 239-245.

[222] P. A. Hansen, J. N. Moore, R. M. Hochstrasser, Determination of the ironcarbonyl bond geometry of carboxyprotoheme in solution using picosecond infrared-optical photoselection, Chem. Phys. 131 (1989) 49-62.

[223] H. P. Trommsdorff, J. M. Zeigler, R. M. Hochstrasser, Narrow-band laserinduced photochemical processes in polysilane solid films at $1.4 \mathrm{~K}$, Chem. Phys. Lett. 154 (1989) 463-467.

[224] R. M. Hochstrasser, Spectroscopy - new aspects of Raman-scattering, Nature 336 (1988) 621-622.

[225] M. Y. Lee, R. M. Hochstrasser, Excited-state photophysics and barrier crossing dynamics of 9,9'-bifluorene, Chem. Phys. Lett. 153 (1988) 1-6.

[226] J. R. Ambroseo, R. M. Hochstrasser, Pathways of relaxation of the n-h stretching vibration of pyrrole in liquids, J. Chem. Phys. 89 (1988) 5956-5957.

[227] H. P. Trommsdorff, J. M. Zeigler, R. M. Hochstrasser, Spectral hole burning in polysilanes, J. Chem. Phys. 89 (1988) 4440-4441.

[228] V. L. Windisch, A. B. Smith, R. M. Hochstrasser, Unimolecular photodissociation of s-tetrazine and derivatives, J. Phys. Chem. 92 (1988) $5366-5370$.

[229] S. M. Janes, G. A. Dalickas, W. A. Eaton, R. M. Hochstrasser, Picosecond transient absorption study of photodissociated carboxy hemoglobin and myoglobin, Biophysical J. 54 (1988) 545-549. 
[230] P. A. Hansen, J. N. Moore, R. M. Hochstrasser, Picosecond time-resolved infrared-spectroscopy, J. Electrochem. Soc. 135 (1988) C387.

[231] J. R. G. Thorne, R. M. Hochstrasser, J. M. Zeigler, Charge-transfer luminescence in polysilanes, J. Electrochem. Soc. 135 (1988) C384.

[232] J. R. G. Thorne, R. M. Hochstrasser, J. M. Zeigler, Photophysics of the phases of poly(di-normal-hexylsilane), J. Phys. Chem. 92 (1988) 4275-4277.

[233] J. N. Moore, P. A. Hansen, R. M. Hochstrasser, Iron carbonyl bond geometries of carboxymyoglobin and carboxyhemoglobin in solution determined by picosecond time-resolved infrared-spectroscopy, Proc. Natl. Acad. Sci. USA 85 (1988) 5062-5066.

[234] Y. R. Kim, M. Lee, J. R. G. Thorne, R. M. Hochstrasser, J. M. Zeigler, Picosecond reorientations of the transition dipoles in polysilanes using fluorescence anisotropy, Chem. Phys. Lett. 145 (1988) 75-80.

[235] R. M. Hochstrasser, Luminescence studies of inertial motion in liquids, J. Lumin. 40-1 (1988) 54-58.

[236] H. P. Trommsdorff, R. M. Hochstrasser, M. Pierre, Optical resolution of hydrogen tunneling levels in benzoic-acid crystals, J. Lumin. 40-1 (1988) 203206.

[237] R. M. Hochstrasser, C. K. Johnson, Biological processes studied by ultrafast laser techniques, Top. Appl. Phys. 60 (1988) 357-417.

[238] E. R. Henry, R. M. Hochstrasser, Molecular-dynamics simulations of fluorescence polarization of tryptophans in myoglobin, Proc. Natl. Acad. Sci. USA 84 (1987) 6142-6146.

[239] A. B. Myers, R. M. Hochstrasser, Resonance Raman depolarization ratios as a probe of excited-state dephasing times, J. Chem. Phys. 87 (1987) 2116-2121.

[240] M. Lee, J. T. Yardley, R. M. Hochstrasser, Dependence of intramolecular proton-transfer on solvent friction, J. Phys. Chem. 91 (1987) 4621-4625.

[241] J. N. Moore, P. A. Hansen, R. M. Hochstrasser, A new method for picosecond time-resolved infrared-spectroscopy - applications to CO photodissociation from iron porphyrins, Chem. Phys. Lett. 138 (1987) 110-114.

[242] R. M. Hochstrasser, H. P. Trommsdorff, Observation of delocalized states of the proton in carboxylic-acid dimers in condensed matter, Chem. Phys. 115 (1987) 1-6.

[243] A. B. Myers, M. A. Pereira, P. L. Holt, R. M. Hochstrasser, Rotationaldynamics of electronically excited aniline in solution from picosecond fluorescence anisotropies, J. Chem. Phys. 86 (1987) 5146-5155.

[244] S. M. Janes, G. Holtom, P. Ascenzi, M. Brunori, R. M. Hochstrasser, Fluorescence and energy-transfer of tryptophans in aplysia myoglobin, Biophysical J. 51 (1987) 653-660. 
[245] R. M. Hochstrasser, Studies of fast inertial and diffusive motions in liquids, Hyperfine Interact. 38 (1987) 635-650.

[246] A. B. Myers, P. L. Holt, M. A. Pereira, R. M. Hochstrasser, Observation of a free rotation transient in hot stilbene vapor, Chem. Phys. Lett. 132 (1986) $585-590$.

[247] A. B. Myers, R. M. Hochstrasser, Time-resolved fluorescence polarization and 4 -wave-mixing from an ensemble of free symmetrical rotors, J. Chem. Phys. 85 (1986) 6301-6314.

[248] E. R. Henry, W. A. Eaton, R. M. Hochstrasser, Molecular-dynamics simulations of cooling in laser-excited heme-proteins, Proc. Natl. Acad. Sci. USA 83 (1986) 8982-8986.

[249] G. R. Holtom, H. P. Trommsdorff, R. M. Hochstrasser, Impurity-induced double proton-transfer in benzoic-acid crystals, Chem. Phys. Lett. 131 (1986) $44-50$.

[250] M. Lee, A. J. Bain, P. J. McCarthy, C. H. Han, J. N. Haseltine, A. B. Smith, R. M. Hochstrasser, Picosecond photoisomerization and rotational reorientation dynamics in solution, J. Chem. Phys. 85 (1986) 4341-4347.

[251] A. B. MYERS, P. L. HOLT, M. A. PEREIRA, R. M. Hochstrasser, Observation of a free rotation transient in hot stilbene vapor, Chem. Phys. Lett. 130 (1986) 265-270.

[252] A. B. MYERS, R. M. Hochstrasser, Comparison of 4-wave-mixing techniques for studying orientational relaxation, IEEE J. Quantum Electron. 22 (1986) $1482-1492$.

[253] M.

Saltzberg, P. K. Davies, R. M. Hochstrasser, G. C. Farrington, Preparation and optical spectroscopy of Na-Bu(ii)-beta-alumina, J. Electrochem. Soc. 133 (1986) C343.

[254] S. A. Payne, R. M. Hochstrasser, Picosecond coherent anti-Stokes Ramanscattering of excited-states, J. Phys. Chem. 90 (1986) 2068-2074.

[255] S. A. Payne, R. M. Hochstrasser, Picosecond transient coherent anti-Stokes Raman-spectroscopy of rhodamine-560 in ethanol, Opt. Lett. 11 (1986) 285287.

[256] A. J. Bain, P. J. McCarthy, R. M. Hochstrasser, Picosecond polarization spectroscopy as a probe of intramolecular dynamics - rovibronic relaxation in the S1 state of trans-stilbene, Chem. Phys. Lett. 125 (1986) 307-312.

[257] R. M. Hochstrasser, The influence of initial conditions on dynamic processes in molecular-solids, J. PHYSIQUE 46 (1985) 501-506.

[258] B. Dick, R. M. Hochstrasser, Fully resonant sum and difference frequency mixing spectroscopy, Ber. Bunsen-Ges. Phys. Chem. 89 (1985) 344-346. 
[259] S. Dasgupta, T. G. Spiro, C. K. Johnson, G. A. Dalickas, R. M. Hochstrasser, Picosecond resonance Raman evidence for unrelaxed heme in the (carbonmonoxy)myoglobin photoproduct, Biochemistry 24 (1985) 52955297.

[260] J. Najbar, W. Jarzeba, R. M. Hochstrasser, Non-radiative decay of the T1 states of chloronaphthalenes and protonated chloroquinolines at $77 \mathrm{~K}$, Chem. Phys. 95 (1985) 1-8.

[261] F. E. Doany, R. M. Hochstrasser, B. I. Greene, R. R. Millard, Femtosecondresolved ground-state recovery of cis-stilbene in solution, Chem. Phys. Lett. 118 (1985) $1-5$.

[262] M. Y. Lee, G. R. Holtom, R. M. Hochstrasser, Observation of the kramers turnover region in the isomerism of trans-stilbene in fluid ethane, Chem. Phys. Lett. 118 (1985) 359-363.

[263] D. K. Negus, D. S. Green, R. M. Hochstrasser, Decay of the fluorescence anisotropy from isolated stilbene molecules, Chem. Phys. Lett. 117 (1985) 409-413.

[264] S. P. Velsko, R. M. Hochstrasser, Principles of time resolved cars studies of molecular-solids, J. Chim. Phys. Phys.-Chim. Biol. 82 (1985) 153-158.

[265] S. Velsko, R. M. Hochstrasser, Theory of vibrational coherence and population decay in isotopically mixed-crystal, J. Chem. Phys. 82 (1985) 2180-2190.

[266] E. J. Heilweil, R. M. Hochstrasser, Nonlinear spectroscopy and picosecond transient grating study of colloidal gold, J. Chem. Phys. 82 (1985) 4762-4770.

[267] S. Velsko, R. M. Hochstrasser, Studies of vibrational-relaxation in lowtemperature molecular-crystals using coherent Raman-spectroscopy, J. Phys. Chem. 89 (1985) 2240-2253.

[268] R. M. Hochstrasser, C. K. Johnson, Lasers in biology, Laser Focus-ElectroOptics 21 (1985) 100.

[269] F. E. Doany, R. M. Hochstrasser, B. I. Greene, Isomerization intermediates in solution phase photochemistry of stilbenes, Proc. Soc. Photo-Optical Instrumentation Eengineers 533 (1985) 25-29.

[270] C. K. Johnson, G. A. Dalickas, S. A. Payne, R. M. Hochstrasser, Picosecond timescale Raman processes and spectroscopy, Pure Appl. Chem. 57 (1985) 195-200.

[271] B. Dick, R. M. Hochstrasser, Non-linear spectroscopic studies using sumfrequency and difference-frequency-generation, Chem. Phys. 91 (1984) 1-11.

[272] R. M. Hochstrasser, R. Moore, Observation of collision-free spectral relaxation in p-difluorobenzene, Chem. Phys. Lett. 105 (1984) 359-362.

[273] B. Dick, R. M. Hochstrasser, Absorption and emission spectroscopies of homogeneous and inhomogeneously broadened multilevel systems in strong light fields, J. Chem. Phys. 81 (1984) 2897-2906. 
[274] T. J. Trout, S. Velsko, R. Bozio, P. L. Decola, R. M. Hochstrasser, Nonlinear Raman-study of line-shapes and relaxation of vibrational-states of isotopically pure and mixed-crystals of benzene, J. Chem. Phys. 81 (1984) 4746-4759.

[275] F. E. Doany, E. J. Heilweil, R. Moore, R. M. Hochstrasser, Picosecond study of an intermediate in the trans to cis isomerization pathway of stiff stilbene, J. Chem. Phys. 80 (1984) 201-206.

[276] J. M. Clemens, R. M. Hochstrasser, H. P. Trommsdorff, Direct studies of proton tunneling in hydrogen-bonded mixed molecular-crystals by opticalexcitation, J. Chem. Phys. 80 (1984) 1744-1753.

[277] D. K. Negus, R. M. Hochstrasser, Molecular-motion and energy-transfer in molecular and biological-systems, J. Lumin. 31-2 (1984) 3-8.

[278] H. P. Trommsdorff, R. Casalegno, R. J. D. Miller, J. M. Clemens, R. M. Hochstrasser, Direct optical studies of proton tunneling in hydrogen-bonded mixed molecular-crystals, J. Lumin. 31-2 (1984) 517-524.

[279] R. Moore, F. E. Doany, E. J. Heilweil, R. M. Hochstrasser, Picosecond timeresolved fluorescence spectroscopy of molecular vapors, J. Phys. Chem. 88 (1984) 876-879.

[280] R. M. Hochstrasser, D. K. Negus, Picosecond fluorescence decay of tryptophans in myoglobin, Proc. Natl. Acad. Sci. USA-Biological Sciences 81 (1984) 43994403.

[281] R. M. Hochstrasser, Correction, Acc. Chem. Res. 17 (1984) 47.

[282] R. M. Hochstrasser, H. P. Trommsdorff, Non-linear optical spectroscopy of molecular-systems, Acc. Chem. Res. 16 (1983) 376-385.

[283] B. Dick, R. M. Hochstrasser, Resonant non-linear spectroscopy in strong fields, Chem. Phys. 75 (1983) 133-155.

[284] B. Dick, R. M. Hochstrasser, Theoretical-analysis of fluorescence excitation, absorption and multiphoton-ionization spectra in strong light fields, Chem. Phys. Lett. 102 (1983) 484-490.

[285] F. Ho, W. S. Tsay, J. Trout, S. Velsko, R. M. Hochstrasser, Picosecond timeresolved cars in isotopically mixed-crystals of benzene, Chem. Phys. Lett. 97 (1983) 141-146.

[286] R. Moore, F. E. Doany, E. J. Heilweil, R. M. Hochstrasser, Energy redistribution in large molecules - direct study of intramolecular relaxation in the gas-phase with picosecond gating, Faraday Discuss. 75 (1983) 331-340.

[287] J. E. Baggott, J. M. Jasinski, A. H. Zewail, K. VonPuttkamer, M. Quack, Y. Haas, J. Troe, B. S. Rabinovitch, E. J. Heller, C. Wittig, T. R. Rizzo, C. C. Hayden, F. F. Crim, M. C. Chuang, R. N. Zare, R. M. Hochstrasser, P. Brumer, S. A. Rice, H. R. Dubal, M. Lewerenz, I. Oref, C. S. Parmenter, C. A. G. O. Varma, J. Pfab, Intramolecular kinetics - general discussion, Faraday Discuss. 75 (1983) 341-363. 
[288] R. N. Zare, P. J. Brucat, A. H. Zewail, H. Watanabe, S. Koda, S. Tsuchiya, R. Naaman, E. K. C. Lee, M. N. R. Ashfold, J. M. Bayley, R. N. Dixon, H. Nakane, D. V. Oconnor, S. Leach, J. Troe, J. H. Callomon, C. A. G. O. Varma, E. Riedle, H. J. Neusser, E. W. Schlag, R. M. Hochstrasser, I. Yamazaki, M. Quack, Intramolecular kinetics - general discussion, Faraday Discuss. 75 (1983) 407-427.

[289] S. Velsko, J. Trout, R. M. Hochstrasser, Quantum beating of vibrational factor group components in molecular-solids, J. Chem. Phys. 79 (1983) 2114-2120.

[290] G. Rothenberger, D. K. Negus, R. M. Hochstrasser, Solvent influence on photoisomerization dynamics, J. Chem. Phys. 79 (1983) 5360-5367.

[291] B. Dick, R. M. Hochstrasser, Spectroscopic and line-narrowing properties of resonant sum and difference frequency generation, J. Chem. Phys. 78 (1983) 3398-3409.

[292] P. A. Cornelius, R. M. Hochstrasser, A. W. Steele, Ultrafast relaxation in picosecond photolysis of nitrosylhemoglobin, J. Mol. Biol. 163 (1983) 119-128.

[293] R. M. Hochstrasser, S. Velsko, Vibrational coherence loss in molecular-solids - theory and experiments on isotopically mixed benzene crystals, J. Opt. Soc. Am. 73 (1983) 1398.

[294] J. M. Clemens, J. Najbar, I. Bronsteinbonte, R. M. Hochstrasser, Dual picosecond dye-lasers synchronously pumped by a mode-locked cw YAG laser, Opt. Commun. 47 (1983) 271-277.

[295] B. Dick, R. M. Hochstrasser, Spectroscopy using sum-frequency and differencefrequency-generation in molecular-solids, PHYSICAL REVIEW LETTERS 51 (1983) 2221-2223.

[296] H. P. Trommsdorff, J. R. Andrews, R. M. Hochstrasser, Excited-state vibrational spectroscopy by multiresonant 4 wave mixing, Appl. Phys. B 28 (1982) $147-148$.

[297] J. A. Syage, W. R. Lambert, P. M. Felker, A. H. Zewail, R. M. Hochstrasser, Picosecond excitation and trans-cis isomerization of stilbene in a supersonic jet - dynamics and spectra, Chem. Phys. Lett. 88 (1982) 266-270.

[298] W. S. Tsay, R. M. Hochstrasser, Picosecond spectroscopy in chemistry and biology, J. Chem. Education 59 (1982) 490-495.

[299] E. J. Heilweil, F. E. Doany, R. Moore, R. M. Hochstrasser, Vibrational-energy relaxation of the cyanide ion in aqueous-solution, J. Chem. Phys. 76 (1982) $5632-5634$.

[300] H. Souma, E. J. Heilweil, R. M. Hochstrasser, Resonant non-linear optical mixing using the phase conjugate configuration - spectroscopic studies, J. Chem. Phys. 76 (1982) 5693-5702.

[301] A. Mehreteab, J. R. Andrews, A. B. Smith, R. M. Hochstrasser, 2-photon excitation and fluorescence lifetimes of silver atoms in rare-gas matrices, J. Phys. Chem. 86 (1982) 888-891. 
[302] J. R. Andrews, R. M. Hochstrasser, Temperature-dependent dephasing of ground and excited-state Raman transitions of pentacene in benzoic-acid, Bull. Am. Phys. Soc. 26 (1981) 13-14.

[303] J. R. Andrews, R. M. Hochstrasser, Identification of new contributions to electronically resonant 4-wave mixing, Bull. Am. Phys. Soc. 26 (1981) 279.

[304] J. R. Andrews, R. M. Hochstrasser, H. P. Trommsdorff, Vibrational transitions in excited-states of molecules using coherent Stokes Raman-spectroscopy application to ferrocytochrome-C, Chem. Phys. 62 (1981) 87-101.

[305] Y. Liang, D. K. Negus, R. M. Hochstrasser, M. Gunner, P. L. Dutton, Picosecond kinetic absorption studies of an iron porphyrin and bacteriochlorophyll using a streak camera, Chem. Phys. Lett. 84 (1981) 236240 .

[306] F. Ho, W. S. Tsay, J. Trout, R. M. Hochstrasser, Direct measurement of the vibrational-relaxation of the $991 \mathrm{~cm}-1$ mode of the benzene crystal, Chem. Phys. Lett. 83 (1981) 5-9.

[307] J. R. Andrews, R. M. Hochstrasser, Comparison of ground-state and excitedstate Raman transitions using resonant coherent Stokes generation, Chem. Phys. Lett. 83 (1981) 427-431.

[308] P. A. Cornelius, A. W. Steele, D. A. Chernoff, R. M. Hochstrasser, The observation of a picosecond transient in the relaxation of an iron porphyrin, Chem. Phys. Lett. 82 (1981) 9-14.

[309] J. R. Andrews, R. M. Hochstrasser, Thermally induced excited-state coherent Raman-spectra of solids, Chem. Phys. Lett. 82 (1981) 381-385.

[310] I. I. Abram, R. M. Hochstrasser, Optical coherence properties of collective molecular-systems - a comparison of the statistical and quantum approaches, J. Chem. Phys. 75 (1981) 337-351.

[311] H. P. Trommsdorff, J. R. Andrews, P. L. Decola, R. M. Hochstrasser, Multiresonant 4 wave mixing in molecular-crystals, J. Lumin. 24-5 (1981) 663665.

[312] P. A. Cornelius, A. W. Steele, D. A. Chernoff, R. M. Hochstrasser, Different dissociation pathways and observation of an excited deoxy state in picosecond photolysis of oxymyoglobin and carboxymyoglobin, Proc. Natl. Acad. Sci. USA-Biological Sciences 78 (1981) 7526-7529.

[313] B. I. Greene, R. M. Hochstrasser, R. B. Weisman, Photoproperties of isolated cis and trans stilbene molecules, Chem. Phys. 48 (1980) 289-298.

[314] J. R. Andrews, R. M. Hochstrasser, Transient grating studies of energy deposition in radiationless processes, Chem. Phys. Lett. 76 (1980) 207-212.

[315] J. R. Andrews, R. M. Hochstrasser, Transient grating effects in resonant 4wave mixing experiments, Chem. Phys. Lett. 76 (1980) 213-217. 
[316] F. E. Doany, B. I. Greene, R. M. Hochstrasser, Excitation-energy effects in the photophysics of trans-stilbene in solution, Chem. Phys. Lett. 75 (1980) 206-208.

[317] P. L. Decola, R. M. Hochstrasser, H. P. Trommsdorff, Vibrational-relaxation in molecular-crystals by 4 -wave mixing - naphthalene, Chem. Phys. Lett. 72 (1980) $1-4$.

[318] M. Paczkowski, R. Pierce, A. B. Smith, R. M. Hochstrasser, Consecutive processes in the photolysis of dimethyl-s-tetrazine molecules in the vaporphase, Chem. Phys. Lett. 72 (1980) 5-9.

[319] I. I. Abram, R. M. Hochstrasser, J. E. Kohl, M. G. Semack, D. White, Decay of vibrational coherence in ortho-para mixtures of solid hydrogen, Chem. Phys. Lett. 71 (1980) 405-408.

[320] D. A. Chernoff, R. M. Hochstrasser, Fluorescence from an upper singlet of aromatic c-nitroso compounds - comment, Chem. Phys. Lett. 70 (1980) 213214.

[321] D. A. Chernoff, A. W. Steele, R. M. Hochstrasser, Sub-nanosecond processes in the hemoglobin-oxygen system, Federation Proceedings 39 (1980) 1648.

[322] R. M. Hochstrasser, L. W. Johnson, C. M. Klimcak, Stark effects on quasilinear chain excitons in dibromonaphthalene, J. Chem. Phys. 73 (1980) 156-162.

[323] R. M. Hochstrasser, G. R. Meredith, H. P. Trommsdorff, Resonant 4 wave mixing in molecular-crystals, J. Chem. Phys. 73 (1980) 1009-1019.

[324] P. L. Decola, J. R. Andrews, R. M. Hochstrasser, H. P. Trommsdorff, Simultaneous narrow-line Raman-spectra of ground and excited electronic states, J. Chem. Phys. 73 (1980) 4695-4696.

[325] R. M. Hochstrasser, C. A. Nyi, Dynamical effects from resonance Raman and fluorescence studies of the molecular exciton system perylene, J. Chem. Phys. 72 (1980) 2591-2600.

[326] I. I. Abram, R. M. Hochstrasser, Theory of the time evolution of exciton coherence in weakly disordered crystals, J. Chem. Phys. 72 (1980) 3617-3625.

[327] R. M. Hochstrasser, C. M. Klimcak, 2nd-Order Stark shifts in the opticalspectrum of anthracene in a naphthalene crystal, Mol. Cryst. Liq. Cryst. 58 (1980) 421-431.

[328] E. Heilweil, R. M. Hochstrasser, H. Souma, Applications of the phase conjugate configuration in non-linear spectroscopy, Opt. Commun. 35 (1980) 227-232.

[329] J. R. Andrews, R. M. Hochstrasser, Femtosecond relaxation of an iron porphyrin observed with polarization spectroscopy in a 3-level system, Proc. Natl. Acad. Sci. USA-Physical Sciences 77 (1980) 3110-3114.

[330] D. A. Chernoff, R. M. Hochstrasser, A. W. Steele, Geminate recombination of $\mathrm{O}_{2}$ and hemoglobin, Proc. Natl. Acad. Sci. USA-Physical Sciences 77 (1980) 5606-5610. 
[331] R. M. Hochstrasser, Picosecond processes in the isomerism of stilbenes, Pure Appl. Chem. 52 (1980) 2683-2691.

[332] R. M. Hochstrasser, Correction, J. Chem. Phys. 72 (1980) 3440.

[333] B. I. Greene, R. M. Hochstrasser, R. B. Weisman, Picosecond spectroscopic studies of the photoisomerization of stilbene, Bull. Am. Phys. Soc. 24 (1979) 501.

[334] B. I. Greene, R. M. Hochstrasser, R. B. Weisman, Spectroscopic study of the picosecond photoisomerization of stilbene, Chem. Phys. Lett. 62 (1979) 427430.

[335] I. I. Abram, R. M. Hochstrasser, J. E. Kohl, M. G. Semack, D. White, Coherence loss for vibrational and librational excitations in solid nitrogen, J. Chem. Phys. 71 (1979) 153-162.

[336] B. I. Greene, R. M. Hochstrasser, R. B. Weisman, Picosecond dynamics of the photoisomerization of trans-stilbene under collision-free conditions, J. Chem. Phys. 71 (1979) 544-545.

[337] R. M. Hochstrasser, C. M. Klimcak, G. R. Meredith, Vibronic spectra of the benzene crystal at $4.2 \mathrm{~K}$ using 2-photon fluorescence excitation, J. Chem. Phys. 70 (1979) 870-880.

[338] R. M. Hochstrasser, C. A. Nyi, Resonance fluorescence, Raman-spectra and relaxation of single vibronic levels in the condensed phase - azulene in naphthalene, J. Chem. Phys. 70 (1979) 1112-1128.

[339] B. I. Greene, R. M. Hochstrasser, R. B. Weisman, Picosecond transient spectroscopy of molecules in solution, J. Chem. Phys. 70 (1979) 1247-1259.

[340] R. M. Hochstrasser, G. R. Meredith, Raman, fluorescence and non-linear properties in molecular solids, J. Lumin. 18-9 (1979) 32-36.

[341] H. P. Trommsdorff, R. M. Hochstrasser, G. R. Meredith, Raman and 2-photon resonances in the 3 wave mixing in organic-crystals - benzene, naphthalene and biphenyl, J. Lumin. 18-9 (1979) 687-692.

[342] B. I. Greene, R. B. Weisman, R. M. Hochstrasser, Coherent anti-Stokes Raman-scattering in gaseous nitrogen with picosecond pulses, Chem. Phys. Lett. 59 (1978) 5-9.

[343] R. M. Hochstrasser, F. A. Novak, 2-level density matrix description of resonance light-scattering, Chem. Phys. Lett. 53 (1978) 3-7.

[344] R. M. Hochstrasser, G. R. Meredith, H. P. Trommsdorff, 2-photon spectra of gases by 3-wave mixing, Chem. Phys. Lett. 53 (1978) 423-428.

[345] R. M. Hochstrasser, C. M. Klimcak, Stark modulation of electronic-spectrum of pyridine in benzene at $1.6 \mathrm{k}$, Chem. Phys. Lett. 53 (1978) 429-432.

[346] R. M. Hochstrasser, C. M. Klimcak, Stark effect study of singlet-triplet absorption of nitrate ion in nano3, J. Chem. Phys. 69 (1978) 2580-2584. 
[347] B. Dellinger, M. A. Paczkowski, R. M. Hochstrasser, A. B. Smith, Observation of transient intermediates in photo-chemical decomposition of substituted stetrazines, J. Am. Chem. Soc. 100 (1978) 3242-3243.

[348] R. M. Hochstrasser, G. W. Scott, A. H. Zewail, Optically detected EPR and low-field endor of triplet benzophenone, Mol. Phys. 36 (1978) 475-499.

[349] B. I. Greene, R. M. Hochstrasser, R. B. Weisman, W. A. Eaton, Spectroscopic studies of oxyhemoglobin and carbonmonoxyhemoglobin after pulsed optical excitation, Proc. Natl. Acad. Sci. USA 75 (1978) 5255-5259.

[350] R. M. Hochstrasser, G. R. Meredith, Applications of lasers in chemical spectroscopy and dynamics - higher-order susceptibility effects, Pure Appl. Chem. 50 (1978) 759-769.

[351] I. Abram, R. M. Hochstrasser, J. E. Kohl, M. G. Semack, D. White, Stimulated Raman-scattering experiments in solid $\mathrm{N}_{2}$ and $\mathrm{H}_{2}$ using nitrogen pumped dyelasers, Chem. Phys. Lett. 52 (1977) 1-4.

[352] R. M. Hochstrasser, F. A. Novak, Effect of fluctuations on emission-spectra practical distinctions between Raman and fluorescence-spectra, Chem. Phys. Lett. 48 (1977) 1-6.

[353] D. S. King, B. Dellinger, R. M. Hochstrasser, A. B. Smith, Laser-induced isotope enrichment in a rare-gas matrix, IEEE J. Quantum Electron. 13 (1977) D98-D99.

[354] R. M. Hochstrasser, F. Novak, C. A. Nyi, Statistical aspects of resonance lightscattering in condensed phase, Isr. J. Chem. 16 (1977) 250-257.

[355] R. M. Hochstrasser, G. R. Meredith, Parity forbidden polariton fusion in molecular-crystals, J. Chem. Phys. 67 (1977) 1273-1274.

[356] R. M. Hochstrasser, H. N. Sung, Electronic and vibrational-states of biphenyl crystals using 2-photon excitation spectroscopy, J. Chem. Phys. 66 (1977) $3265-3275$.

[357] R. M. Hochstrasser, H. N. Sung, Vibronic spectra of naphthalene crystal at 1.6k using 2-photon fluorescence excitation, J. Chem. Phys. 66 (1977) 32763296.

[358] D. S. King, C. T. Denny, R. M. Hochstrasser, A. B. Smith, Photochemical decomposition of 1,4-s-tetrazine- ${ }^{15} \mathrm{n}_{2}$, J. Am. Chem. Soc. 99 (1977) 271-273.

[359] B. Dellinger, D. S. King, R. M. Hochstrasser, A. B. Smith, Laser-induced isotope enrichment in a rare-gas matrix, J. Am. Chem. Soc. 99 (1977) 31973198.

[360] R. M. Hochstrasser, D. S. King, A. B. Smith, Spectroscopy, photophysics, and photochemistry of dimethyl-s-tetrazine and phenyl-s-tetrazine in crystals and mixed-crystals at low-temperatures, J. Am. Chem. Soc. 99 (1977) 3923-3933. 
[361] B. Dellinger, R. M. Hochstrasser, A. B. Smith, Measurements of relative chemical reactivity of triplet spin substates, J. Am. Chem. Soc. 99 (1977) $5834-5835$.

[362] B. Dellinger, D. S. King, R. M. Hochstrasser, A. B. Smith, High-resolution optical spectroscopy and laser isotope enrichment of matrix-isolated s-tetrazine in argon, J. Am. Chem. Soc. 99 (1977) 7138-7142.

[363] R. M. Hochstrasser, Ramsey fringes in optical spectroscopy, Nature 268 (1977) $17-18$.

[364] R. M. Hochstrasser, D. L. Narva, Dependence of triplet yield on excitationenergy in all-trans and 11-cis retinal, Photochem. Photobiol. 26 (1977) 595599.

[365] R. M. Hochstrasser, Isotopically selective chemistry in solids using tunable lasers, Bull. Am. Phys. Soc. 22 (1977) 417.

[366] R. M. Hochstrasser, D. L. Narva, A. C. Nelson, Picosecond photophysics of trans-retinal, Chem. Phys. Lett. 43 (1976) 15-19.

[367] R. W. Anderson, R. M. Hochstrasser, H. J. Pownall, Picosecond absorptionspectra of 2nd excited singlet-state of a molecule in condensed phase xanthione, Chem. Phys. Lett. 43 (1976) 224-227.

[368] R. M. Hochstrasser, D. S. King, A. C. Nelson, Subnanosecond dynamics of fluorescence and singlet absorption of s-tetrazine, Chem. Phys. Lett. 42 (1976) $8-12$.

[369] R. M. Hochstrasser, F. A. Novak, Theory of resonant light-scattering, Chem. Phys. Lett. 41 (1976) 407-412.

[370] R. M. Hochstrasser, Proceedings of 1975 international-conference on luminescence - tokyo, japan - september 1-5, 1975 - concluding remarks, J. Lumin. 12 (1976) 959-962.

[371] R. W. Anderson, R. M. Hochstrasser, Dynamics of photodissociation in solution using picosecond spectroscopy, J. Phys. Chem. 80 (1976) 2155-2159.

[372] J. M. Friedman, R. M. Hochstrasser, Approximate selection-rules for resonance Raman-spectroscopy, J. Am. Chem. Soc. 98 (1976) 4043-4048.

[373] R. M. Hochstrasser, D. S. King, Isotopically selective spectroscopy and photochemistry of sigma-tetrazine in crystals and mixed crystals at lowtemperature, J. Am. Chem. Soc. 98 (1976) 5443-5450.

[374] R. G. Bray, R. M. Hochstrasser, 2-photon absorption by rotating diatomicmolecules, Mol. Phys. 31 (1976) 1199-1211.

[375] R. M. Hochstrasser, A. C. Nelson, Study of energy-transfer between electronically excited-states using a picosecond laser-pulse, Opt. Commun. 18 (1976) 361-366. 
[376] G. W. Scott, R. W. Anderson, R. M. Hochstrasser, H. Lutz, Picosecond studies of radiationless transitions in aromatic-hydrocarbons and ketones, Bull. Am. Phys. Soc. 20 (1975) 46.

[377] R. M. Hochstrasser, G. W. Scott, A. H. Zewail, H. Fuess, Optical and magneticresonance properties of triplet-state of biphenyl- $\mathrm{H}_{10}$ in biphenyl- $\mathrm{D}_{10}$ and $4.2 \mathrm{~K}$ neutron-diffraction of biphenyl- $\mathrm{D}_{10}$, Chem. Phys. 11 (1975) 273-279.

[378] R. G. Bray, R. M. Hochstrasser, H. N. Sung, 2-photon excitation-spectra of molecular gases - new results for benzene and nitric-oxide, Chem. Phys. Lett. 33 (1975) 1-4.

[379] J. M. Friedman, R. M. Hochstrasser, Use of fluorescence quenchers in resonance Raman-spectroscopy, Chem. Phys. Lett. 33 (1975) 225-227.

[380] R. W. Anderson, R. M. Hochstrasser, H. Lutz, G. W. Scott, Direct measurements of internal-conversion between excited electronic states of a molecule in condensed phase, Chem. Phys. Lett. 32 (1975) 204-209.

[381] J. Friedman, R. M. Hochstrasser, Interference effects in resonance Ramanspectroscopy, Chem. Phys. Lett. 32 (1975) 414-419.

[382] R. M. Hochstrasser, D. S. King, Isotopically selective photochemistry in molecular-crystals, J. Am. Chem. Soc. 97 (1975) 4760-4762.

[383] R. M. Hochstrasser, J. E. Wessel, Time resolved fluorescence of anthracene in mixed-crystals at 2K, Chem. Phys. 6 (1974) 19-33.

[384] J. M. Friedman, R. M. Hochstrasser, Moderately high resolution fluorescencespectrum of $\mathrm{S}_{1}-\mathrm{S}_{0}$ transition of azulene, Chem. Phys. 6 (1974) 145-154.

[385] J. M. Friedman, R. M. Hochstrasser, Time-dependence of resonant and near resonant photon molecular-interactions, Chem. Phys. 6 (1974) 155-165.

[386] R. M. Hochstrasser, D. S. King, Absorption, fluorescence and phosphorescence spectra of singlet and triplet-states of s-tetrazine in crystal and in mixedcrystals at low-temperatures, Chem. Phys. 5 (1974) 439-447.

[387] R. M. Hochstrasser, A. H. Zewail, Optical and magnetic-resonance spectra of linear-chain excitons, Chem. Phys. 4 (1974) 142-150.

[388] R. W. Anderson, R. M. Hochstrasser, H. Lutz, G. W. Scott, Measurements of intersystem crossing kinetics using $3545 \AA$ picosecond pulses nitronaphthalenes and benzophenone, Chem. Phys. Lett. 28 (1974) 153-157.

[389] R. G. Bray, R. M. Hochstrasser, J. E. Wessel, Continuously tunable 2 photon excitation of individual rotational levels of a 2-sigma-t state of nitric-oxide, Chem. Phys. Lett. 27 (1974) 167-171.

[390] R. M. Hochstrasser, J. E. Wessel, Detailed selection-rules and herzberg-teller theory for 2-photon absorption in molecules having $\mathrm{D}_{2 h}$ and $\mathrm{D}_{6 h}$ symmetry - particularly naphthalene and benzene in solid state, Chem. Phys. Lett. 24 (1974) 1-6. 
[391] R. M. Hochstrasser, H. N. Sung, J. E. Wessel, Moderate-resolution study of 2-photon spectrum of ${ }^{1} \mathrm{~B}_{2 u}$ state of benzene- $\mathrm{h}_{6}$ and benzene- $\mathrm{d}_{6}$, Chem. Phys. Lett. 24 (1974) $7-10$.

[392] R. M. Hochstrasser, H. Lutz, G. W. Scott, Dynamics of populating lowest triplet-state of benzophenone following singlet excitation, Chem. Phys. Lett. 24 (1974) 162-167.

[393] R. M. Hochstrasser, H. N. Sung, J. E. Wessel, Moderate-resolution 2-photon spectrum of naphthalene crystal and naphthalene in durene, Chem. Phys. Lett. 24 (1974) 168-171.

[394] R. W. Anderson, R. M. Hochstrasser, H. Lutz, G. W. Scott, Direct measurements of energy-transfer between triplet-states of molecules in liquids using picosecond pulses, J. Chem. Phys. 61 (1974) 2500-2506.

[395] R. M. Hochstrasser, J. E. Wessel, H. N. Sung, 2-photon excitation spectrum of benzene in gas-phase and crystal, J. Chem. Phys. 60 (1974) 317-318.

[396] R. M. Hochstrasser, T. Y. Li, H. N. Sung, J. Wessel, A. H. Zewail, Experimental studies of triplet exciton bands of molecular-crystals, Pure Appl. Chem. 37 (1974) 85-96.

[397] J. M. Friedman, R. M. Hochstrasser, A description of resonant Raman scattering in hemeproteins: cytochrome-C, Chem. Phys. 1 (1973) 457-467.

[398] R. M. Hochstrasser, Electric-field effects on oriented molecules and molecularcrystals, Acc. Chem. Res. 6 (1973) 263-269.

[399] R. M. Hochstrasser, A. H. Zewail, Magnetic sensitivity of $3330.8 \AA$ state of s-triazine, Chem. Phys. Lett. 21 (1973) 15-16.

[400] R. M. Hochstrasser, L. W. Johnson, T. H. P, Stark effects on low-energy electronic states of para-benzoquinone single-crystals, Chem. Phys. Lett. 21 (1973) 251-255.

[401] R. M. Hochstrasser, J. E. Wessel, Radiative decay of benzophenone lowpressure gas, Chem. Phys. Lett. 19 (1973) 156-161.

[402] R. M. Hochstrasser, G. W. Scott, A. H. Zewail, Optical, magnetic-resonance, and endor studies of $\mathrm{n}-\pi$ triplet-state of benzophenone in mixed-crystals, J. Chem. Phys. 58 (1973) 393-395.

[403] R. M. Hochstrasser, H. N. Sung, J. E. Wessel, High-resolution 2-photon excitation-spectra, J. Chem. Phys. 58 (1973) 4694-4695.

[404] R. M. Hochstrasser, R. D. McAlpine, J. D. Whiteman, Low-energy magnetic and electric dipole transitions of biphenyl crystal, J. Chem. Phys. 58 (1973) $5078-5088$.

[405] R. M. Hochstrasser, H. N. Sung, J. E. Wessel, 2-photon excitation-spectra new and versatile spectroscopic tool, J. Am. Chem. Soc. 95 (1973) 8179-8180. 
[406] R. M. Hochstrasser, Spin-orbit coupling in s-triazine, Chem. Phys. Lett. 17 (1972) 1-6.

[407] R. M. Hochstrasser, Phosphorescence capability of n- $\pi$ states, Chem. Phys. Lett. 15 (1972) 316.

[408] R. M. Hochstrasser, D. A. Wiersma, Distortion of excited molecules in organic solids, Isr. J. Chem. 10 (1972) 517.

[409] R. M. Hochstrasser, D. A. Wiersma, Reassignment of $n-\pi$ transitions of phthalazine, J. Chem. Phys. 56 (1972) 528.

[410] R. M. Hochstrasser, A. H. Zewail, T. S. Lin, Mixed magnetic and electric dipole transition in s-triazine, J. Chem. Phys. 56 (1972) 637.

[411] R. M. Hochstrasser, P. N. Prasad, Phonon sidebands of electronic transitions in molecular-crystals and mixed-crystals, J. Chem. Phys. 56 (1972) 2814.

[412] R. M. Hochstrasser, J. D. Whiteman, Exciton band-structure and properties of a real linear chain in a molecular crystal, J. Chem. Phys. 56 (1972) 5945.

[413] R. M. Hochstrasser, C. J. Marzzacco, Emission and absorption-spectra of pyrimidine at 4.2 degrees k, J. Mol. Spectrosc. 42 (1972) 75.

[414] R. M. Hochstrasser, J. W. Michaluk, Optical and electric-field effects in singlet and triplet-states of dichlorobenzophenone crystal, J. Mol. Spectrosc. 42 (1972) 197.

[415] R. M. Hochstrasser, T. Y. Li, Spectral manifestations of nonradiative processes in azulene, J. Mol. Spectrosc. 41 (1972) 297.

[416] R. M. Hochstrasser, Stark effects and electric dipole coupling of n pi and pi pi states, Mol. Phys. 24 (1972) 597.

[417] R. M. Hochstrasser, Correction, J. Chem. Phys. 57 (1972) 1018.

[418] R. M. Hochstrasser, P. N. Prasad, Some aspects of spin-lattice relaxation amongst triplet states of molecules and molecular excitons, Chem. Phys. Lett. 9 (1971) 113-114.

[419] R. M. Hochstrasser, P. N. Prasad, Different spectra for different sites in mixed crystals, Chem. Phys. Lett. 8 (1971) 315-317.

[420] R. M. Hochstrasser, A. H. Zewail, Stark and Zeeman effects on singlet $n-\pi$ state of s-triazine, Chem. Phys. Lett. 11 (1971) 157.

[421] R. M. Hochstrasser, J. E. Wessel, J. D. Whiteman, A. H. Zewail, Characterization of triplet states of axially symmetric benzenes using Zeeman effect, Chem. Phys. Lett. 10 (1971) 452.

[422] R. M. Hochstrasser, P. N. Prasad, Some aspects of spin-lattice relaxation amongst triplet states of molecules and molecular excitons, Chem. Phys. Lett. 9 (1971) 113. 
[423] R. M. Hochstrasser, P. N. Prasad, Different spectra for different sites in mixed crystals, Chem. Phys. Lett. 8 (1971) 315.

[424] R. M. Hochstrasser, J. E. Wessel, A. H. Zewail, Zeeman effect studies of triplet states of benzene, J. Chem. Phys. 55 (1971) 3596.

[425] R. M. Hochstrasser, J. W. Michaluk, Excited state dipole moment of pyridine, J. Chem. Phys. 55 (1971) 4668.

[426] R. M. Hochstrasser, A. H. Zewail, Studies of $3455 \AA$ triplet state of s-triazine, J. Chem. Phys. 55 (1971) 5291.

[427] R. M. Hochstrasser, D. A. Wiersma, Structure and dipole moment of first electronically excited state of pyridine N-oxide, J. Chem. Phys. 55 (1971) 5339.

[428] R. M. Hochstrasser, A. H. Zewail, Optical spectroscopic determination of zerofield splitting in vibronic levels of triplet state of nitrite, J. Chem. Phys. 54 (1971) 2979.

[429] R. M. Hochstrasser, D. A. Wiersma, Zeeman effect in electronic spectrum of solid $\mathrm{CS}_{2}$, J. Chem. Phys. 54 (1971) 4165.

[430] R. M. Hochstrasser, L. J. Noe, Excited state dipole moments of benzophenone in singlet and triplet n- $\pi$ states, J. Mol. Spectrosc. 38 (1971) 175.

[431] G. Castro, R. M. Hochstrasser, A high magnetic field study of the triplet state of hexachlorobenzene, Chem. Phys. Lett. 6 (1970) 180-182.

[432] R. M. Hochstrasser, L. J. Noe, Excited state dipole moments of phenanthrene: Electric field modulation of the luminescence, Chem. Phys. Lett. 5 (1970) 489-492.

[433] R. M. Hochstrasser, T. S. Lin, Optical and magnetic field studies of lowest triplet state of pyrazine crystal, J. Chem. Phys. 53 (1970) 2676.

[434] R. M. Hochstrasser, A. P. Marchetti, Theory of singlet-triplet transitions in cyclic tetramers - applications to tetraphenyl group-4 compounds, J. Chem. Phys. 52 (1970) 1360.

[435] R. M. Hochstrasser, A. P. Marchetti, Spectra of solid $\mathrm{SO}_{2}$ in ${ }^{3} \mathrm{~B}_{1^{-}}{ }^{1} \mathrm{~A}_{1}$ region, J. Mol. Spectrosc. 35 (1970) 335.

[436] R. M. Hochstrasser, Correction, J. Chem. Phys. 52 (1970) 1624.

[437] S. Dym, R. M. Hochstrasser, Spin-orbit coupling and radiationless transitions in aromatic ketones, J. Chem. Phys. 51 (1969) 2458.

[438] R. H. Clarke, R. M. Hochstrasser, C. J. Marzzacco, Crystal field effects on triplet states of molecular solids - electronic staes of quinoxaline, J. Chem. Phys. 51 (1969) 5015.

[439] T. F. Hunter, R. D. McAlpine, R. M. Hochstrasser, Triplet-triplet energy transfer in ordered and random media, J. Chem. Phys. 50 (1969) 1140. 
[440] R. M. Hochstrasser, L. J. Noe, Dipole moments of excited states of azulene, J. Chem. Phys. 50 (1969) 1684.

[441] R. M. Hochstrasser, A. P. Marchetti, Electronic vibrational and Zeeman spectra of triplet $\mathrm{NO}_{2}^{-}$, J. Chem. Phys. 50 (1969) 1727.

[442] R. H. Clarke, R. M. Hochstrasser, Location and assignment of lowest triplet state of perylene, J. Mol. Spectrosc. 32 (1969) 309.

[443] R. M. Hochstrasser, A. P. Marchetti, The polarization of the allowed triplettriplet absorption in anthracene, Chem. Phys. Lett. 1 (1968) 597-598.

[444] R. M. Hochstrasser, Analytical and structural aspects of vibronic interactions in ultraviolet spectra of organic molecules, Acc. Chem. Res. 1 (1968) 266.

[445] R. M. Hochstrasser, C. Marzzacco, Perturbations between electronic states in aromatic and heteroaromatic molecules, J. Chem. Phys. 49 (1968) 971.

[446] W. A. Eaton, R. M. Hochstrasser, Single-crystal spectra of ferrimyoglobin complexes in polarized light, J. Chem. Phys. 49 (1968) 985.

[447] R. M. Hochstrasser, T. S. Lin, Magnetic and electric field spectra of organic crystals - optical measurements of zero-field splittings, J. Chem. Phys. 49 (1968) 4929.

[448] R. M. Hochstrasser, L. J. Noe, Stark splitting in molecular crystals, J. Chem. Phys. 48 (1968) 514.

[449] G. Castro, R. M. Hochstrasser, Electronic Zeeman measurements on 14 dibromonaphthalene, J. Chem. Phys. 48 (1968) 637.

[450] S. DYM, R. M. Hochstrasser, M. Schafer, Assignment of lowest triplet state of carbonyl group, J. Chem. Phys. 48 (1968) 646.

[451] R. H. Clarke, R. M. Hochstrasser, Polarization of transitions to magnetic substates of triplet excitons, J. Chem. Phys. 48 (1968) 1745.

[452] R. M. Hochstrasser, G. J. Small, Spectra and structure of mixed organic crystals, J. Chem. Phys. 48 (1968) 3612.

[453] R. M. Hochstrasser, C. Marzzacco, $n-\pi$ Transitions in a diazine - phthalazine, J. Chem. Phys. 48 (1968) 4079.

[454] R. H. Clarke, R. M. Hochstrasser, Electronic Zeeman effect in naphthalene crystal, J. Chem. Phys. 49 (1968) 3313.

[455] R. M. Hochstrasser, Correction, J. Chem. Phys. 49 (1968) 4730.

[456] R. M. Hochstrasser, Polarization of triplet factor group states, J. Chem. Phys. 47 (1967) 1015.

[457] R. H. Clarke, R. M. Hochstrasser, Factor group splitting and Zeeman splitting of lowest triplet state of phenazine, J. Chem. Phys. 47 (1967) 1915. 
[458] G. Castro, R. M. Hochstrasser, Triplet states of naphthalene derivatives .1. 1,4-dibromonaphthalene, J. Chem. Phys. 47 (1967) 2241.

[459] W. A. Eaton, R. M. Hochstrasser, Electronic spectrum of single crystals of ferricytochrome-C, J. Chem. Phys. 46 (1967) 2533.

[460] G. Castro, R. M. Hochstrasser, Singlet-triplet transitions in p-dihalogenated benzenes, J. Chem. Phys. 46 (1967) 3617.

[461] R. M. Hochstrasser, C. Marzzacco, Singlet-triplet transitions in o-diazines pyridazine, J. Chem. Phys. 46 (1967) 4155.

[462] R. H. Clarke, R. M. Hochstrasser, Electronic Zeeman effect in anthracene, J. Chem. Phys. 46 (1967) 4532.

[463] R. M. Hochstrasser, Phosphorescence of molecular crystals, Appl. Spectrosc. 21 (1967) 406.

[464] R. M. Hochstrasser, Triplet state in chemistry and physics, Physics Today 20 (1967) 95.

[465] R. M. Hochstrasser, Study of intermolecular interaction by electronic spectroscopy, Radiation Research 31 (1967) 587.

[466] R. M. Hochstrasser, Electronic spectra of organic molecules, Annu. Rev. Phys. Chem. 17 (1966) 457.

[467] R. M. Hochstrasser, G. J. Small, Electronic spectra of phenanthrene in mixed crystals, J. Chem. Phys. 45 (1966) 2270.

[468] G. Castro, R. M. Hochstrasser, Triplet state excimers, J. Chem. Phys. 45 (1966) 4352.

[469] R. M.

Hochstrasser, C. Marzzacco, Electronic states of 9,10-diazaphenanthrene, J. Chem. Phys. 45 (1966) 4681.

[470] G. Castro, R. M. Hochstrasser, Singlet-triplet absorption spectra of single crystals of p-dihalogenated benzenes, J. Chem. Phys. 44 (1966) 412.

[471] R. M. Hochstrasser, R. D. McAlpine, On nonconfirmation of dual emission properties of biphenylene, J. Chem. Phys. 44 (1966) 3325.

[472] G. Castro, R. M. Hochstrasser, Triplet exciton effects in single crystals of p-diiodobenzene, Mol. Cryst. 1 (1966) 139.

[473] G. Castro, R. M. Hochstrasser, Spin orbital coupling and the Zeeman effect in molecular crystals, Solid State Commun. 3 (1965) 425-428.

[474] J. A. Mullins, A. D. Adler, R. M. Hochstrasser, Vapor spectra of porphyrins, J. Chem. Phys. 43 (1965) 2548-2550.

[475] R. M. Hochstrasser, G. J. Small, Multiplet structure in absorption fluorescence and phosphorescence of mixed molecular crystals, Chem. Commun. 5 (1965) 87. 
[476] R. M. Hochstrasser, M. A, Polarization of excimer fluorescence from pyrene and perylene crystals, J. Chem. Phys. 42 (1965) 2243.

[477] R. M. Hochstrasser, Energies of electronic configurations of transition metals, J. Chem. Education 42 (1965) 154.

[478] W. R. Cullen, B. R. Green, R. M. Hochstrasser, Spectra of arylarsines .2. spectral manifestations of charge transfer character, J. Inorg Nucl. Chem. 27 (1965) 641.

[479] R. M. Hochstrasser, S. K. Lower, C. Reid, Absolute ultraviolet-absorption intensities of anthra-cene-trinitrobenzene crystal, J. Mol. Spectrosc. 15 (1965) 257.

[480] R. M. Hochstrasser, C. Reid, S. K. Lower, Experimental evidence for localized excitons in spectra of charge-transfer complex molecular crystals, J. Chem. Phys. 41 (1964) 1073.

[481] R. M. Hochstrasser, Determination of efficiency of triplet energy migration in benzophenone crystals, J. Chem. Phys. 40 (1964) 1038.

[482] R. M. Hochstrasser, S. K. Lower, Polarized emission + triplet-triplet absorption spectra of aromatic hydrocarbons in benzophenone crystals, J. Chem. Phys. 40 (1964) 1041.

[483] R. M. Hochstrasser, Spectral effects of strong exciton coupling in lowest electronic transition of perylene, J. Chem. Phys. 40 (1964) 2559.

[484] R. M. Hochstrasser, T. F. Hunter, Photoprocesses involving triplet states of organic crystals, J. Chem. Phys. 40 (1964) 2737.

[485] R. M. Hochstrasser, M. Kasha, Application of the exciton model to monomolecular lamellar systems, Photochem. Photobiol. 3 (1964) 317-331.

[486] R. M. Hochstrasser, Correction, J. Chem. Phys. 40 (1964) 3121.

[487] R. M. Hochstrasser, Photoprocesses in the organic solid state, Photochem. Photobiol. 3 (1964) 299-306.

[488] R. M. Hochstrasser, Transfer of triplet excitation energy in benzophenone crystals, J. Chem. Phys. 39 (1963) 3153.

[489] R. M. Hochstrasser, Problem of defects in relation to optical properties of organic molecular crystals, Radiat. Res. 20 (1963) 107.

[490] R. M. Hochstrasser, Mixed dimer emission from pyrene crystals containing perylene, J. Chem. Phys. 36 (1962) 1099.

[491] R. M. Hochstrasser, Absorption spectrum of phenazine single crystals at 77 degrees and 4.2 degrees $\mathrm{K}$ in region of $\mathrm{n}-\pi$ transition, J. Chem. Phys. 36 (1962) 1808. 
[492] R. M. Hochstrasser, S. K. Lower, Polarization of spectra of crystalline azobenzene and mixed crystals of azobenzene in stilbene at 77 degrees and 4.2 degrees $\mathrm{K}$ in region of lowest $\mathrm{n}-\pi$ transition, J. Chem. Phys. 36 (1962) 3505 .

[493] R. M. Hochstrasser, Influence of temperature on emission spectra of stilbene monocrystals and mixed crystals with tetracene, J. Mol. Spectrosc. 8 (1962) 485.

[494] R. M. Hochstrasser, Luminescence of organic molecular crystals, Rev. Mod. Phys. 34 (1962) 531.

[495] S. K. Lower, R. M. Hochstrasser, C. Reid, The polarized charge-transfer spectrum of crystalline anthracene-tnb complex, Mol. Phys. 4 (1961) 161-168.

[496] R. M. Hochstrasser, The luminescence of complex molecules in relation to the internal conversion of excitation energy .2. n-heteroaromatics, Can. J. Chem. 38 (1960) 233-239.

[497] R. M. Hochstrasser, Polarization of the 1st 2 electronic transitions of pyrene, J. Chem. Phys. 33 (1960) 459-463.

[498] R. M. Hochstrasser, Electronic absorption spectrum of diphenylene in substitutional solid-solid solution, J. Chem. Phys. 33 (1960) 950-951.

[499] R. M. Hochstrasser, G. B. Porter, Primary processes in photo-oxidation, Quartery Reviews 14 (1960) 146-173.

[500] R. M. Hochstrasser, On the problem of radiative combinations between upper singlet states and the ground state in aromatic molecules, Spectrochim. Acta 16 (1960) 497-504.

[501] W. R. Cullen, R. M. Hochstrasser, The electronic spectra of the arylarsines .1. the nature of the transitions in the phenylarsines and the relative influence of $-\mathrm{CH}_{3}$ and influence $-\mathrm{CF}_{3}$ groups, J. Mol. Spectrosc. 5 (1960) 118-132.

[502] R. M. Hochstrasser, Note on the photooxidation of tetramethylrubrene, Can. J. Chem. 37 (1959) 1123-1125.

[503] R. M. Hochstrasser, The luminescence of complex molecules in relation to the internal conversion of excitation energy .1., Can. J. Chem. 37 (1959) 13671372 .

[504] R. M. Hochstrasser, Internal conversion in polyatomic molecules, Spectrochim. Acta 15 (1959) 756.

[505] R. M. Hochstrasser, M. Ritchie, The photoformation and thermal decomposition of rubrene peroxide, Transactions of the Faraday Society 52 (1956) 1363-1373. 